\title{
Influence of Buckwheat and Buckwheat Sprouts Flours on the Nutritional and Textural Parameters of Wheat Buns
}

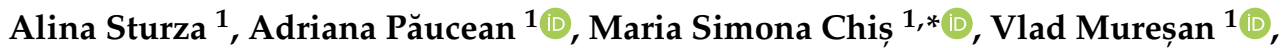 \\ Dan Cristian Vodnar $\left.{ }^{2,3}{ }^{(}\right)$, Simona Maria Man ${ }^{1}{ }^{\circledR}$, Adriana Cristina Urcan ${ }^{4}(\mathbb{D}$, \\ Iulian Eugen Rusu ${ }^{1}$, Georgiana Fostoc ${ }^{1}$ and Sevastița Muste ${ }^{1}$ \\ 1 Department of Food Engineering, Faculty of Food Science and Technology, University of Agricultural \\ Sciences and Veterinary Medicine of Cluj-Napoca, 3-5 Mănăştur Street, 400372 Cluj-Napoca, Romania; \\ alina.sturza@usamvcluj.ro (A.S.); adriana.paucean@usamvcluj.ro (A.P.); vlad.muresan@usamvcluj.ro (V.M.); \\ simona.man@usamvcluj.ro (S.M.M.); iulian.rusu@usamvcluj.ro (I.E.R.); georgiana_fostoc@yahoo.com (G.F.); \\ sevastita.muste@usamvcluj.ro (S.M.) \\ 2 Department of Food Science, Faculty of Food Science and Technology, University of Agricultural Sciences \\ and Veterinary Medicine of Cluj-Napoca, 3-5 Mănăştur Street, 400372 Cluj-Napoca, Romania; \\ dan.vodnar@usamvcluj.ro \\ 3 Institute of Life Sciences, University of Agricultural Sciences and Veterinary Medicine Cluj-Napoca, \\ 3-5 Calea Mănăştur, 400372 Cluj-Napoca, Romania \\ 4 Department of Microbiology and Immunology, University of Agricultural Sciences and Veterinary Medicine, \\ 3-5 Mănăştur Street, 400372 Cluj-Napoca, Romania; adriana.urcan@usamvcluj.ro \\ * Correspondence: simona.chis@usamvcluj.ro; Tel.: +40-742-009731
}

Received: 19 October 2020; Accepted: 9 November 2020; Published: 10 November 2020 updates

\begin{abstract}
In recent years, food products manufactured with buckwheat and sprouts flours have attracted widespread interest due to their high nutritional value with various health benefits, becoming more and more popular. The purpose of this study was to assesses the influence of buckwheat and sprouts flours on the nutritional, sensorial and textural characteristics on the final baked products. In order to achieve these goals, methods like HPLC-RID (High-Perfomance Liquid Chromatography with Refractive Index Detection), aluminum chloride colorimetric assay, Folin-Ciocalteu and 1,1-Diphenyl-2-picrylhydrazyl (DPPH) were used to determine fructose, glucose, sucrose, maltose; total flavonoids, total phenols and antioxidant activity. Sensorial analysis was realized by using hedonic test and texture profile was performed on a CT 3 Texture Analyzer. The results proved that wheat flour could be successfully replaced by $20 \%$ buckwheat and $10 \%$ sprouts flours, respectively, improving their nutritional value, without negative influence on texture parameters and sensorial features. The obtained buns were accepted by consumers with a total hedonic score of 9.1 and 8.7, respectively. Hardness, gumminess and adhesiveness were improved by using Magimix improver, meanwhile cohesiveness, springiness, gumminess and adhesiveness were improved by using guar gum.
\end{abstract}

Keywords: buckwheat flour; buckwheat sprouts; buns; quality and textural parameters

\section{Introduction}

The base of human food pyramid are cereal-based products due to their nutritional value rich in carbohydrates, proteins and lipids that provides $56 \%$ of the total energy world consumption and $50 \%$ of the protein consumed globally [1]. Wheat (Triticum aestivum) is one of the main cereal crops used worldwide in bakery manufacturing [2]. However, through wheat milling various bioactive compounds amount could be reduced or even lost [2-4]. 
During the last decades, consumer requirements regarding bakery products became more focused towards products obtained from unconventional flours or from composite ones. Pseudocereals such as buckwheat, quinoa and amaranth have gained the researches attention due to their precious chemical composition rich in fibers, proteins, phenolic acids, flavonoids, fatty acids, vitamins and minerals [5-9], which are known for their benefits on human health [5].

Buckwheat is a pseudocereal with a significant level of proteins in comparison to cereals (wheat, sorghum, corn, rice etc.) with a range between $7-21 \%$, being easily digestible [8]. This pseudocereal is also rich in minerals, especially in copper, manganese, iron, potassium, sodium and zinc $[5,10,11]$. Likewise, buckwheat is known for its B complex vitamin content, vitamins E and PP $[9,12]$ as well as for its high dietary fibers content [13]. Its bioactive compounds such as phenolic acids and flavonoids (rutin and quercitin mainly) contribute to a rich antioxidant capacity, with multiple positive implications on consumers health [14-16].

Recently, sprouts consumption has increased mainly because of their nutritional value an excellent source of proteins, fibers, vitamins, minerals and various bioactive compounds. Germination facilitates the improvement of digestibility by increasing the bioavailability of minerals and increases the phenolic content, which could enhance the antioxidant activity [17-20].

In light of this evidence, buckwheat and buckwheat sprouts help to prevent and treat various diseases such as oxidative anxiety, neurodegenerative disorders, cardiovascular diseases and even skin cancer. These functional properties increased their application in food and pharmaceutical products manufacturing [21].

Considering that both buckwheat and sprouts flours are gluten-free, their introduction in bread manufacturing process represent a new technology challenge in order to obtain products with desirable sensorial characteristics; therefore, the introduction of some improvers such as special enzymes or hydrocolloids is necessary to mimic gluten network, which is responsible for dough structure [22,23].

Guar gum is an inexpensive and renewable additive used in various industries; however, its main use is in the food industry [24,25]. In breadmaking, guar ensures uniform hydration of the flour, improving the kneading and shaping of the dough. The high-water absorption capacity leads to a desired consistency of the dough. As a result, final baked products have a higher level of moisture retention even after baking, and the storage time is considered to be longer $[24,26,27]$.

Xylanase, alpha-amylase and glucose oxidase are enzymes used in the bakery industry due to their various benefits. There are several studies which have reported that alpha amylase optimizes the ability to retain gases in the dough, promotes the increase in volume of products and their elasticity, improves color and helps to extend the shelf life by decreasing the crumb hardness [28,29]. Regarding xylanase, several authors reported an improvement of sensory parameters such as finer texture; more uniform crumb structure; lower adhesiveness; better color, taste and aroma as the control sample [30,31].

It is considered that the addition of glucose oxidase improves the qualities of the dough due to the strengthening effect of the gluten network, an important function especially in the case of lean flours. The use of this enzyme helps to obtain baked goods with increased volume and improves crumb properties [32].

This research aimed to establish the optimum addition levels of buckwheat and sprouted buckwheat flours on the final baked buns and to assesses their influence from the nutritional, sensorial and textural parameters. Hydrocolloids like guar gum and complex baking improver were used in order to improve the buns' texture parameters. 


\section{Materials and Methods}

\subsection{Experimental Design}

In the buns manufacturing, the buckwheat flour and sprouted buckwheat flour were mixed in different percentages with wheat flour $(10 \%, 20 \%$ and $30 \%$ respectively). The flours mixes were further entitled as composite flours.

The buns formulation contained the following ingredients: composite flours consisting of wheat flour, buckwheat and sprouted buckwheat flours, in different percentages $(10 \%, 20 \%$, and $30 \%$ respectively), water, salt, yeast, guar gum and Magimix improver, as showed in Tables 1 and 2. The following codes were used for composite flours with 10, 20, 30\% buckwheat flour (BW): 10BW, 20BW and 30BW, meanwhile for composite flour with sprouts flour (SF) the abbreviations were: 10SF, 20SF and 30SF, respectively.

Table 1. Buns recipe by adding buckwheat flour.

\begin{tabular}{cccccccc}
\hline \multirow{2}{*}{ Sample } & \multicolumn{7}{c}{ Ingredients [\%] } \\
\cline { 2 - 8 } & Wheat Flour & BW Flour & Water & Salt & Yeast & G & M \\
\hline WF & 100 & 0 & 60.7 & 2 & 2 & \\
10BW1 & 90 & 10 & 68 & 2 & 2 & 0.2 \\
20BW1 & 80 & 20 & 76.5 & 2 & 2 & 0.2 & \\
30BW1 & 70 & 30 & 81.1 & 2 & 2 & 0.2 & 0.2 \\
10BW2 & 90 & 10 & 68 & 2 & 2 & & 0.2 \\
20BW2 & 80 & 20 & 76.5 & 2 & 2 & 2 \\
30BW2 & 70 & 30 & 81.1 & 2 & 2 & & 0.2 \\
\hline
\end{tabular}

WF: wheat flour, control sample; BW: flour-buckwheat flour; G: guar gum; M: baking improver Magimix; 10BW1, 20BW1, 30BW1: buns with 10\%, 20\%, 30\% buckwheat flour addition and $0.2 \%$ guar gum; 10BW2, 20BW2, 30BW2: buns with $10 \%, 20 \%, 30 \%$ buckwheat flour and $0.2 \%$ Magimix.

Table 2. Buns recipe by adding sprouted buckwheat flour.

\begin{tabular}{cccccccc}
\hline \multirow{2}{*}{ Sample } & \multicolumn{7}{c}{ Ingredients [\%] } \\
\cline { 2 - 8 } & Wheat Flour & SF Flour & Water & Salt & Yeast & G & M \\
\hline 10SF1 & 90 & 10 & 60.7 & 2 & 2 & 0.2 & \\
20SF1 & 80 & 20 & 60.7 & 2 & 2 & 0.2 & \\
30SF1 & 70 & 30 & 60.7 & 2 & 2 & 0.2 & \\
10SF2 & 90 & 10 & 60.7 & 2 & 2 & & 0.2 \\
20SF2 & 80 & 20 & 60.7 & 2 & 2 & 0.2 \\
30SF2 & 70 & 30 & 60.7 & 2 & 2 & & 0.2 \\
\hline
\end{tabular}

SF flour: sprouted buckwheat flour, G: guar gum, M: baking improver Magimix; 10SF1, 20SF1, 30SF1: buns with $10 \%, 20 \%, 30 \%$ sprouted buckwheat flour and $0.2 \%$ guar gum; 10SF2, 20SF2, 30SF2: buns with $10 \%, 20 \%, 30 \%$ sprouted buckwheat flour and $0.2 \%$ Magimix.

Buns were obtained by mixing all ingredients for 3 min at medium speed and 4 min at high speed, by using a mixer (KitchenAid ${ }^{\circledR}$ Precise Heat Mixing Bowl., Greenville, OH, USA). The doughs were left to leaven for $23 \mathrm{~h}$ at $2-4{ }^{\circ} \mathrm{C}$. After the cold fermentation, doughs were left for leavening for $1 \mathrm{~h}$ at $29{ }^{\circ} \mathrm{C}$ and $80 \%$ relative humidity. This stage aims to raise the temperature of the doughs as close as possible to the temperature of the final leavening; further, doughs were divided and shaped into buns weighing $120 \mathrm{~g}$ and left for final fermentation for $30 \mathrm{~min}$ at $30{ }^{\circ} \mathrm{C}$ and $75 \%$ relative humidity in a thermoclimatic chamber (Zanolli, Verona, Italy). The baking of buns samples was carried out in a professional oven for $30 \mathrm{~min}$ at $220^{\circ} \mathrm{C}$ (Zanolli, Verona, Italy). After baking, buns were left to cool at room temperature for $1 \mathrm{~h}$, before being packaged and stored until testing. 


\subsection{Materials}

Wheat flour was produced by a local Romanian mill (Europan, Sarmasag, Romania) and sold as type 550 according to ash content by Romanian classification (moisture $14.3 \%$, wet gluten $29.3 \%$ and Falling Number $340 \mathrm{~s}$. Buckwheat flour (BW) and green seeds were purchased from the health Romanian food stores; compressed yeast Fala (Bonopan) and salt from the local market. Guar gum and the complex baking improver Magimix-Bonopan (which contains alpha-amylase, maltogenic alpha-amylase, amyloglucosidase, glucose oxidase, xylanase, lipase and ascorbic acid) were acquired from Romanian ingredients market specialized on bakery industry (Lessafre-Marcq-en-Baroeul, France) and Solina Group (Alba Iulia, Romania).

The sugars standards were purchased from Merck (Darmstadt, Germany), and the analytical reagents and chemicals were acquired from Sigma Aldrich (St. Louis, MO, USA), being analytical grade.

\subsection{Buckwheat Sprouts (SF) Manufacturing}

In order to obtain buckwheat sprouts, achenes were soaked and germinated using the EasyGreen Germinator (EasyGreen factory, Langlade, France) at the temperature of $23-25^{\circ} \mathrm{C}$ for 5 days (first $24 \mathrm{~h}$ by maintaining the light and $96 \mathrm{~h}$ by alternating: $12 \mathrm{~h}$ of light and $12 \mathrm{~h}$ of darkness). During germinating, seeds were sprayed with a mixture of tap and distilled water 1:1 $v / v$ for 15 min every $12 \mathrm{~h}$. Sprouted buckwheat achenes were dried in a food drier Biovita-DEH450 (Cluj-Napoca, Romania) at $35^{\circ} \mathrm{C}$ for $24 \mathrm{~h}$; flour was obtained by using a grinding machine ZBPP (Sadkiewicz-Instruments, Bydgoszcz, Poland) and sieved until the $0.6 \mathrm{~mm}$ granulation was reached. Afterward was stored at $20^{\circ} \mathrm{C}$ until further analysis.

\subsection{Physico-Chemical Analyses}

Physico-chemical parameters of the raw materials and of the final baked products like moisture, ash, protein (total nitrogen $\times 5.7$ ), lipids were determined according to AACC approved methods 44-15.02, 08-01.01, 46-11 A and 30-25.01, respectively (AACC-American Association of Cereal Chemists [33]). TTA (total titrable acidity) was determined by using a WTW pH-meter (Hanna Instruments, Vöhringen, Germany) and expressed as $\mathrm{mL}$ of $\mathrm{NaOH}$, according to Corsetti et al., [34].

\subsection{Free Sugars Estimation}

Free sugars were analyzed by HPLC (High-Performance Liquid Chromatography) and the samples extraction was realized as follows: $2.5 \mathrm{~g}$ of sample was dissolved in distilled water $(40 \mathrm{~mL})$ and transferred quantitatively into a $50 \mathrm{~mL}$ volumetric flask and filled up to the mark with water. The solution was filtered through a $0.45 \mu \mathrm{m}$ membrane filter (Millipore, Merck $164 \mathrm{KGaA}$, Darmstadt, Germany), collected in sample vials and placed in an autosampler for analysis. The HPLC analysis of the free sugars was carried out on a modified Alltima Amino 100 stainless steel column (Hicrom, Berkshire, UK), with the following characteristics: $4.6 \mathrm{~mm}$ diameter, $250 \mathrm{~mm}$ length, particle size $5 \mu \mathrm{m}$, according to the method developed by Bonta et al. [35]. The High Performance Liquid Chromatograph (LC -10AD VP model, Shimadzu, Kyoto, Japan) was equipped with degasser, two pumps, autosampler, thermostat oven, controller and refractive index detector. The injection volume was $10 \mu \mathrm{L}$ and the flow rate $1.3 \mathrm{~mL} / \mathrm{min}$. The mobile phase was a solution composed by of acetonitrile and ultrapure water $(80 / 20 v / v)$. For the quantification of main sugars, different calibration curves in the range of 50-0.25 g/100 g (fructose 50-20 g/100 g; glucose 10-40 g/100 g; sucrose 0.3-15 g/100 g; turanose, maltose, isomaltose, erlose $0.25-5 \mathrm{~g} / 100 \mathrm{~g}$ ), with regression coefficients $\left(\mathrm{R}^{2}\right)$ higher of 0.998 were used. The results are expressed in $\mathrm{g} / 100 \mathrm{~g}$ f.w. (fresh weight).

\subsection{Methanolic Samples Extraction}

In order to analyze total flavonoids, total phenols and antioxidant activity, samples were prepared according to Bunea et al. [36] and Păucean et al. [37], with some modifications. Briefly, $1 \mathrm{~g}$ of sample, in 
three replicated each, was mixed with $100 \mathrm{~mL}$ of acidified methanol $\left(\mathrm{CH}_{3} \mathrm{OH}: \mathrm{HCl}, 85: 15 v / v\right)$. Extraction was carried out for $1 \mathrm{~h}$ at room temperature using a stirrer (Velp magnetic stirrer, Usmate (MB)-Italy). Afterwards, the samples were maintained for $23 \mathrm{~h}$ at $4-8^{\circ} \mathrm{C}$ and the mixture was filtered under vacuum through Whatman filter paper no.1. The filtrates were combined in a total extracts and the solvent was removed by using a vacuum-evaporator (Laborota 4010 digital rotary evaporator, Heidolph Instruments $\mathrm{GmbH} \& \mathrm{Co} . \mathrm{KG}$, Schwabach, Germany) at $35^{\circ} \mathrm{C}$, until the extraction solvent became colorless. The residue was recovered with/in $10 \mathrm{~mL}$ of methanol and filtered through a nylon filter $0.45 \mu \mathrm{m}$ (Millipore, Merck KGaA, Darmstadt, Germany); the obtained extracts were stored at $-20{ }^{\circ} \mathrm{C}$ until use.

\subsection{Determination of Total Flavonoids Content}

Flavonoids were measured by the aluminum chloride colorimetric assay adapted for use on a 96-well microplate reader (Synergy ${ }^{\mathrm{TM}}$ HT BioTek Instruments, Winooski, VT, USA), using quercetin as reference standard [38,39]. A volume of $25 \mu \mathrm{L}$ of sample was added into $100 \mu \mathrm{L}$ distilled water and $10 \mu \mathrm{L}$ of $5 \%$ sodium nitrate $\left(\mathrm{NaNO}_{2}\right)$ solution. After $5 \mathrm{~min}, 15 \mu \mathrm{L}$ of $10 \%$ aluminum chloride $(\mathrm{AlCl} 3)$ was added and the samples were maintained to rest for $5 \mathrm{~min}$.

Afterward, $50 \mu \mathrm{L}$ of $1 \mathrm{M}$ sodium hydroxide was added to the mixture and $50 \mu \mathrm{L}$ of distilled water, respectively. Absorbance of the mixture was measured at $510 \mathrm{~nm}$. A standard curve of quercetin was used to establish the final amount of total flavonoids content $\left(y=0.0003 x+0.0029, R^{2}=0.9916\right)$ and the results were expressed as $\mathrm{mg}$ quercetin equivalents (mg QE/100 $\mathrm{g}$ ). The assays were run in triplicate.

\subsection{Total Phenolic Estimation}

The total phenolic content from flours and final products was expressed as gallic acid equivalents/100 $\mathrm{g}$ of fresh product and determined using Folin-Ciocalteu method, adapted by Đorđević et al. [40] and Chis et al. [41]. Briefly, in a $10 \mathrm{~mL}$ volumetric flask, $100 \mu \mathrm{L}$ of methanolic extract was mixed with $1 \mathrm{~mL}$ of distilled water and $500 \mathrm{~mL}$ of Folin-Ciocalteu's reagent; after $10 \mathrm{~s}$ of shaking and $5 \mathrm{~min}$ of rest at room temperature, $5 \mathrm{~mL}$ of $7.5 \%$ sodium carbonate solution was added. Distilled water was used until the graduation marking of the flask was reached. The obtained mixtures were allowed to stand for $90 \mathrm{~min}$ in a dark place without shaking. The absorbance was measured at $760 \mathrm{~nm}$ in a spectrophotometer (Shimadzu Scientific Instruments, Kyoto, Japan), meanwhile methanol was used as blank.

\subsection{Antioxidant Activity}

Antioxidant capacity was determined by reacting $0.1 \mathrm{~mL}$ methanolic extract with $3.9 \mathrm{~mL}$ of 0.025 g/L 2,2-diphenyl-1-picryl-hydrazyl (DPPH) as described by Đorđević et al. [40] and Chis et al. [42] with small modifications. The absorbance of samples was read in triplicate at $515 \mathrm{~nm}$ by using a spectrophotometer Shimadzu 1700 (Shimadzu Scientific Instruments, Kyoto, Japan). Results were expressed as a percentage against the absorbance of the standard DPPH solution according to the following equation: radical scavenging ability $(\mathrm{RSA})(\%)=\left[\left(\mathrm{A}_{0}-\mathrm{A}_{1}\right) / \mathrm{A}_{0}\right] \times 100$, where $\mathrm{A}_{0}$ was the absorbance of the control (blank, without extracts), $\mathrm{A}_{1}$ was the absorbance in the presence of the samples of the extracts. Methanol was used as a blank.

\subsection{Rheological Assessment}

Texture profile analysis of the buns was performed by using a Brookfield CT3 Texture Analyzer (Brookfield Engineering Labs, Middleboro, MA, USA) equipped with $10 \mathrm{~kg}$ load cell and the TA11/1000 cylindrical probe (25.4 mm diameter AOAC Standard Clear Acrylic $21 \mathrm{~g}, 35 \mathrm{~mm}$ length; $40 \%$ target deformation, $1 \mathrm{~mm} \mathrm{~s}^{-1}$ test and post-test speed, $5 \mathrm{~g}$ trigger load, and $5 \mathrm{~s}$ recovery time) having as reference the method described by Păucean et al. [36] and Man et al. [43].

Baked samples were left $2 \mathrm{~h}$ before the assessment to cool, after cut into cube with side of $25 \mathrm{~mm}$, placed on the analyzer plate and compressed twice with cylindrical probe. Texture parameters 
like hardness 1 and 2, total work 1 and 2, cohesiveness, springiness, chewiness, gumminess and adhesiveness were calculated using Texture Pro CT V1.6 software (Brookfield Engineering Labs, Middleboro, MA, USA). Hardness 1 and hardness 2 are defined as the peak force of the first and second compression cycles, respectively, meanwhile total work 1 and total work 2 represent the energy required to deform the samples during the two compression cycles.

\subsection{Sensorial Analysis}

From the sensorial point of view characteristics like appearance, texture, color, taste, flavor and overall acceptability were analyzed by 25 semi-trained panelists, staff and students of the Faculty of Food Science and Technology (70\% female and 30\% male, range 19-63 years), from Cluj-Napoca, Romania. A nine hedonic test was used for the evaluation of these parameters, ranging for 9 as like extremely to 1 as dislike extremely, according to the method described by Chis et al. [41].

\subsection{Statistical Analysis}

Data were analyzed using one-way ANOVA followed by a post hoc Duncan's multiple comparison test, performed in GraphPad Prism8 Software (San Diego, CA, USA), with a confidence interval of 95\%, $p<0.05$. The results of three independent $(n=3)$ replicates were averaged and expressed as mean \pm standard deviations.

\section{Results and Discussions}

\subsection{Flours Characterization}

\subsubsection{Physico-Chemical Parameters of Flours}

The physico-chemical parameters obtained for wheat, buckwheat and sprouted buckwheat flours are presented in Table 3. The results indicated that the levels of ash, total fat, protein and fibers were significantly higher in sprouted buckwheat flours compared to buckwheat and wheat flours, respectively.

Table 3. Physico-chemical parameters of flours.

\begin{tabular}{ccccccc}
\hline Sample & $\begin{array}{c}\text { Moisture Content } \\
{[\%]}\end{array}$ & $\begin{array}{c}\text { Ash } \\
{[\%]}\end{array}$ & $\begin{array}{c}\text { Total Fat } \\
{[\%]}\end{array}$ & $\begin{array}{c}\text { Protein } \\
{[\%]}\end{array}$ & $\begin{array}{c}\text { Fibers } \\
{[\%]}\end{array}$ & $\begin{array}{c}\text { TTA } \\
\text { [\%] }\end{array}$ \\
\hline WF & $10.55 \pm 0.23^{\mathrm{d}}$ & $0.54 \pm 0.11^{\mathrm{a}}$ & $1.36 \pm 16^{\mathrm{a}}$ & $10.80 \pm 0.25^{\mathrm{a}}$ & $1.14 \pm 0.11^{\mathrm{a}}$ & $1.93 \pm 0.10^{\mathrm{a}}$ \\
BW & $9.24 \pm 0.27^{\mathrm{a}}$ & $1.64 \pm 0.10^{\mathrm{d}, \mathrm{e}}$ & $2.36 \pm 0.11^{\mathrm{c}}$ & $12.23 \pm 0.23^{\mathrm{c}, \mathrm{d}}$ & $4.08 \pm 0.24^{\mathrm{e}}$ & $5.40 \pm 0.21^{\mathrm{f}}$ \\
10BW & $10.36 \pm 0.31^{\mathrm{c}, \mathrm{d}}$ & $0.71 \pm 0.12^{\mathrm{a}, \mathrm{b}}$ & $1.69 \pm 0.15^{\mathrm{a}, \mathrm{b}}$ & $11.14 \pm 0.32^{\mathrm{a}, \mathrm{b}}$ & $1.78 \pm 0.10^{\mathrm{b}}$ & $2.43 \pm 0.16^{\mathrm{b}}$ \\
20BW & $10.25 \pm 0.34^{\mathrm{b}, \mathrm{c}}$ & $0.88 \pm 0.15^{\mathrm{b}, \mathrm{c}}$ & $1.83 \pm 0.17^{\mathrm{a}, \mathrm{b}, \mathrm{c}}$ & $11.42 \pm 0.11^{\mathrm{a}, \mathrm{b}, \mathrm{c}}$ & $2.03 \pm 0.25^{\mathrm{b}}$ & $2.97 \pm 0.12^{\mathrm{c}}$ \\
30BW & $10.10 \pm 0.25^{\mathrm{b}}$ & $1.05 \pm 0.22^{\mathrm{c}}$ & $2.03 \pm 0.19^{\mathrm{b}, \mathrm{c}}$ & $11.67 \pm 0.22^{\mathrm{a}, \mathrm{b}, \mathrm{c}}$ & $2.53 \pm 0.21^{\mathrm{i}, \mathrm{c}, \mathrm{d}}$ & $3.50 \pm 0.20^{\mathrm{d}}$ \\
SF & $9.16 \pm 0.19^{\mathrm{a}}$ & $2.53 \pm 0.34^{\mathrm{f}}$ & $5.54 \pm 0.22^{\mathrm{f}}$ & $18.75 \pm 0.56^{\mathrm{f}}$ & $4.67 \pm 0.12^{\mathrm{f}}$ & $4.37 \pm 0.16^{\mathrm{e}}$ \\
10SF & $10.36 \pm 0.27^{\mathrm{c}, \mathrm{d}}$ & $1.00 \pm 0.17^{\mathrm{c}}$ & $2.23 \pm 0.18^{\mathrm{b}, \mathrm{c}}$ & $12.14 \pm 0.31^{\mathrm{b}, \mathrm{c}, \mathrm{d}}$ & $2.02 \pm 0.10^{\mathrm{b}}$ & $2.33 \pm 0.12^{\mathrm{a}, \mathrm{b}}$ \\
20SF & $10.26 \pm 0.32^{\mathrm{b}, \mathrm{c}}$ & $1.42 \pm 0.23^{\mathrm{d}}$ & $3.06 \pm 0.21^{\mathrm{d}}$ & $12.83 \pm 0.32^{\mathrm{d}, \mathrm{e}}$ & $2.48 \pm 0.15^{\mathrm{c}}$ & $2.63 \pm 0.25^{\mathrm{b}, \mathrm{c}}$ \\
30SF & $10.18 \pm 0.25^{\mathrm{b}, \mathrm{c}}$ & $1.76 \pm 0.27^{\mathrm{e}}$ & $3.90 \pm 0.11^{\mathrm{e}}$ & $13.66 \pm 0.25^{\mathrm{e}}$ & $2.96 \pm 0.11^{\mathrm{d}}$ & $3.00 \pm 0.11^{\mathrm{c}}$ \\
\hline
\end{tabular}

WF: wheat flour; BW flour: buckwheat flour; 10BW, 20BW, 30BW: composite flour with 10\%, 20\%, 30\% buckwheat flour addition; SF flour: sprouted buckwheat flour; 10SF, 20SF, 30SF: composite flour with 10\%, 20\%, 30\% sprouted buckwheat flour. Different lowercase letters within a column indicate significant differences between the means of the same parameter analyzed at $p<0.05$ and $(n=3)$ according to Duncan's multiple range test. All results are expressed to fresh weight (f.w.) product.

In the present study, the SF protein content $(18.75 \%)$ is in line with the values presented by Lim Kim et al. [44] (19\%) and Lee and Kim [45] (19.35 $\pm 2.14 \%)$, respectively. Kim et al. [44] reported also higher levels for ash (2.82\%) and fibers (4.39\%) of sprouts compared to seeds $(2.80 \%$ ash and $3.82 \%$ fiber contents). In this light, Lee and Kim [45] reported a value of $3.51 \%$ ash for sprouts and $1.78 \%$ for ungerminated seeds. With respect to total lipid amount, a higher level of total lipids in sprouts compared to seeds $(2.59 \%$ and $3.02 \%$, respectively) were reported [44,45]. 
Regarding the composite flours, the partial addition of these unconventional flours to wheat flour, led to an enrichment of samples from a physico-chemical point of view (Table 3), where buckwheat sprouts flour had a greater impact on these parameters.

\subsubsection{Free Sugars Content of Flours}

The free sugars determined in the present study were: glucose, sucrose, maltose and fructose, as showed in Table 4 . The main sugar from the analyzed flours was glucose $(4.80 \%)$ which was identified in higher extent amount in SF flour, meanwhile WF and BW flours reached smaller values such as $0.07 \%$ and $0.03 \%$, respectively. Fructose, was the second major sugar identified in a bigger amount in SF flour $(2.5 \%)$, followed by sucrose which was identified mainly in BW flour $(0.74 \%)$. The presence of glucose and fructose in SF flour could be justified by the germination process which lead to the degradation of disaccharides, trisaccharides and tetrasaccharides into simple sugars in order to provide the energy needed for the sprouts grow [34,46,47].

Table 4. Free sugars content of flour samples.

\begin{tabular}{ccccc}
\hline Sample & $\begin{array}{c}\text { Glucose } \\
{[\%]}\end{array}$ & $\begin{array}{c}\text { Sucrose } \\
{[\%]}\end{array}$ & $\begin{array}{c}\text { Maltose } \\
{[\%]}\end{array}$ & $\begin{array}{c}\text { Fructose } \\
{[\%]}\end{array}$ \\
\hline RT $(\mathrm{min})$ & 11.20 & 17.80 & 22.70 & 9.10 \\
\hline WF & $0.07 \pm 0.01^{\mathrm{a}}$ & $0.21 \pm 0.02^{\mathrm{a}}$ & $0.07 \pm 0.02^{\mathrm{d}}$ & $0.05 \pm 0.01^{\mathrm{a}}$ \\
BW & $0.03 \pm 0.01^{\mathrm{a}}$ & $0.74 \pm 0.05^{\mathrm{d}}$ & $0.11 \pm 0.10^{\mathrm{f}}$ & $0.20 \pm 0.05^{\mathrm{a}}$ \\
10BW & $0.08 \pm 0.02^{\mathrm{a}}$ & $0.26 \pm 0.01^{\mathrm{a}, \mathrm{b}}$ & $0.07 \pm 0.01^{\mathrm{d}}$ & $0.07 \pm 0.01^{\mathrm{a}}$ \\
20BW & $0.08 \pm 0.02^{\mathrm{a}}$ & $0.30 \pm 0.01^{\mathrm{b}, \mathrm{c}}$ & $0.07 \pm 0.01^{\mathrm{d}}$ & $0.08 \pm 0.01^{\mathrm{a}}$ \\
30BW & $0.07 \pm 0.01^{\mathrm{a}}$ & $0.35 \pm 0.02^{\mathrm{c}}$ & $0.08 \pm 0.01^{\mathrm{e}}$ & $0.09 \pm 0.02^{\mathrm{a}}$ \\
SF & $4.80 \pm 0.12^{\mathrm{d}}$ & $0.27 \pm 0.05^{\mathrm{a}, \mathrm{b}}$ & $0.02 \pm 0.01^{\mathrm{a}}$ & $2.50 \pm 0.10^{\mathrm{c}}$ \\
10SF & $0.94 \pm 0.08^{\mathrm{b}}$ & $0.21 \pm 0.08^{\mathrm{a}}$ & $0.06 \pm 0.01^{\mathrm{c}}$ & $0.21 \pm 0.01^{\mathrm{a}}$ \\
20SF & $2.00 \pm 0.10^{\mathrm{c}}$ & $0.21 \pm 0.05^{\mathrm{a}}$ & $0.06 \pm 0.01^{\mathrm{c}}$ & $0.40 \pm 0.05^{\mathrm{a}, \mathrm{b}}$ \\
30SF & $2.61 \pm 0.09^{\mathrm{c}}$ & $0.23 \pm 0.04^{\mathrm{a}}$ & $0.05 \pm 0.01^{\mathrm{b}}$ & $0.63 \pm 0.05^{\mathrm{b}}$ \\
\hline
\end{tabular}

RT = retention time; WF: wheat flour; BW flour: buckwheat flour; 10BW, 20BW, 30BW: composite flour with 10\%, $20 \%, 30 \%$ buckwheat flour addition; SF flour-sprouted buckwheat flour, 10SF, 20SF, 30SF: composite flour with 10\%, $20 \%, 30 \%$ sprouted buckwheat flour. Different lowercase letters within a column indicate significant differences between the means of the same parameter analyzed at $p<0.05$ and $(n=3)$ according to Duncan's multiple range test.

Sucrose was the major compound in buckwheat $(0.74 \%)$ and belongs to the category of low-molecular-weight sugars; Mazza and Omah reported also that sucrose has the highest amount among the low-molecular-weight sugars in buckwheat flour [48].

With respect to WF sugars content, sucrose was the mainly simple sugar identified $(0.21 \%)$, followed by glucose $(0.07 \%)$, maltose $(0.07 \%)$ and fructose $(0.05 \%)$. The results are similar to those reported by Codina et al. [49] who identified for WF values of $0.05 \%$ for glucose, maltose and fructose and $0.2 \%$ for sucrose, respectively. Sahlström et al. [50] analyzed flours from six wheat cultivars and obtained values between $0.04-0.05 \%$ for glucose, $0.188-0.246 \%$ for sucrose, $0.44-0.063 \%$ for maltose, but a higher value for fructose $0.79-1.04 \%$.

Therefore, composite flours with BW had higher values for sucrose and maltose, meanwhile flours with added SF obtained higher levels of glucose and fructose as shown in Table 4.

\subsubsection{Total Flavonoid Content of Flours}

The increased interest for the use of buckwheat and sprouts in food industry is also due to their flavonoid content, which are important compounds with an antioxidant role.

The total flavonoid of sprouted buckwheat flour was $659.92 \mathrm{mg} \mathrm{QE} / 100 \mathrm{~g}$ f.w. Other studies reported values of $1500 \mathrm{mg} / 100 \mathrm{~g}$ f.w. [51] or values in the range of 100-1250 mg/100 g f.w. [52]. The differences between values could be explained by the buckwheat varieties but also by time and germination condition. An important germination condition could be the absence or presence of light and also its type (e.g., blue, red, fluorescent). 
As illustrated in Table 3 buckwheat flour has a lower amount of flavonoids $-275.58 \mathrm{mg}$ QE/100 $\mathrm{g}$ compared with SF flour, which reached a value of $659.92 \mathrm{mg} \mathrm{QE} / 100 \mathrm{~g}$. The total flavonoids content of buckwheat flour was reported by the literature in a range of $67-225 \mathrm{mg} / 100 \mathrm{~g}$ by Qin et al. [47], meanwhile, Ren et al., [53] reported a value of $400 \mathrm{mg} / 100 \mathrm{~g}$ for buckwheat flour. The differences between the results could be explained by the buckwheat varieties and the cultivating conditions Qin et al. [47] such as the fertilizer soil treatments with Azospirillum and Azobacter [54].

As it was expected, the content of total flavonoids in wheat flour extract was the lowest: $10.10 \mathrm{mg}$ QE/100 g compared to sprouted buckwheat and buckwheat flours, respectively.

Partial substitution of wheat flour resulted on a significant increase of total flavonoids amount in composite flours; 10BW, 20BW and 30BW reached values of $38.71 \mathrm{mg} \mathrm{QE} / 100 \mathrm{~g}, 67.30 \mathrm{mg}$ QE/100 $\mathrm{g}$ and $99.96 \mathrm{mg} \mathrm{QE} / 100 \mathrm{~g}$, respectively. Furthermore, 10SF, 20SF and 30SF samples had even higher values: $72.71 \mathrm{mg}$ QE/100 g, $140.73 \mathrm{mg}$ QE/100 g and $211.73 \mathrm{mg}$ QE/100 g.

\subsubsection{Total Phenolic Content of Flours}

Sprouted buckwheat flour has a higher phenol content (678 mg GAE/100 g f.w.) compared to buckwheat and wheat flours which reached values of $365.67 \mathrm{mg} \mathrm{GAE} / 100 \mathrm{~g}$ f.w. and $43.17 \mathrm{mg}$ GAE/100 g f.w, respectively as illustrated in Table 5 These results are consistent with the values reported by Alvarez-Jubete et al. [7] who obtained values of $670 \pm 12.3 \mathrm{mg} \mathrm{GAE} / 100 \mathrm{~g}$ for buckwheat sprouts, $323 \pm 14.1 \mathrm{mg} \mathrm{GAE} / 100 \mathrm{~g}$ for buckwheat and $53.1 \pm 2.8 \mathrm{mg} \mathrm{GAE} / 100 \mathrm{~g}$ for wheat.

Table 5. Total flavonoids, total phenols and radical scavenging activity of flour samples.

\begin{tabular}{cccc}
\hline Sample & $\begin{array}{c}\text { Total Flavonoid Content } \\
\text { [mg QE/100 g f.w.] }\end{array}$ & $\begin{array}{c}\text { Total Polyphenol Content } \\
\text { [mg GAE/100 g f.w.] }\end{array}$ & $\begin{array}{c}\text { Radical Scavenging Activity } \\
\text { [\%] }\end{array}$ \\
\hline WF & $10.10 \pm 0.21^{\mathrm{a}}$ & $43.17 \pm 0.18^{\mathrm{a}}$ & $39.18 \pm 0.15^{\mathrm{a}}$ \\
BW & $275.58 \pm 0.56^{\mathrm{g}}$ & $365.67 \pm 0.39^{\mathrm{f}}$ & $62.56 \pm 0.31^{\mathrm{d}}$ \\
10BW & $38.71 \pm 0.14^{\mathrm{b}}$ & $54.33 \pm 0.22^{\mathrm{a}}$ & $45.15 \pm 0.25^{\mathrm{b}}$ \\
20BW & $67.30 \pm 0.22^{\mathrm{c}}$ & $77.00 \pm 0.31^{\mathrm{b}}$ & $48.54 \pm 0.51^{\mathrm{b}, \mathrm{c}}$ \\
30BW & $99.96 \pm 0.34^{\mathrm{d}}$ & $96.83 \pm 0.25^{\mathrm{c}}$ & $50.83 \pm 0.48^{\mathrm{b}, \mathrm{c}}$ \\
SF & $659.92 \pm 0.61^{\mathrm{h}}$ & $678.00 \pm 0.70^{\mathrm{g}}$ & $87.31 \pm 0.24^{\mathrm{e}}$ \\
10SF & $72.71 \pm 0.24^{\mathrm{c}}$ & $78.83 \pm 0.27^{\mathrm{b}}$ & $47.05 \pm 0.31^{\mathrm{b}, \mathrm{c}}$ \\
20SF & $140.73 \pm 0.35^{\mathrm{e}}$ & $150.17 \pm 0.29^{\mathrm{d}}$ & $52.54 \pm 0.20^{\mathrm{c}}$ \\
30SF & $211.73 \pm 0.49^{\mathrm{f}}$ & $218.83 \pm 0.32^{\mathrm{e}}$ & $59.04 \pm 0.14^{\mathrm{d}}$ \\
\hline
\end{tabular}

f.w.: fresh weight; WF: wheat flour; BW flour: buckwheat flour, 10BW, 20BW, 30BW: composite flour with 10\%, 20\%, $30 \%$ buckwheat flour addition; SF flour: sprouted buckwheat flour; 10SF, 20SF, 30SF: composite flour with 10\%, 20\%, $30 \%$ sprouted buckwheat flour. Different lowercase letters within a column indicate significant differences between the means of the same parameter analyzed at $p<0.05$ and $(\mathrm{n}=3)$ according to Duncan's multiple range test.

Partial replacement of wheat flour in different percentages $(10 \%, 20 \%$ and $30 \%)$ with buckwheat flour and sprouted buckwheat flour respectively, led to an increase of the phenolic content in composite flours (Table 5). This could be explained due to the higher total phenols content of buckwheat and sprouts flours compared to wheat flour.

\subsubsection{Radical Scavenging Activity of Flours}

The results for the raw materials radical scavenging activity (RSA) are presented in Table 5 Sprouted buckwheat flour was characterized with the higher radical scavenging activity $87.31 \%$, followed by buckwheat flour with a score of $62.56 \%$. Wheat flour had the lowest value for this parameter: $39.18 \%$. As expected, the composite flours with the addition of sprouted buckwheat flour showed higher values than the composite flours with the addition of buckwheat flour as follows: 10SF:47.05\%, 20SF:52.54\%, 30SF:59.04\%, while 10BW:45.54\%, 20BW:48.54\%, 30BW:50.83\%.

Zhang et al. [21] reported a similar value for sprouted buckwheat flour. Some authors explained the high antioxidant activity of sprouted buckwheat flour by the fact that germination enhanced the 
accumulation of antioxidant compounds. There is also mentioned in the literature, that the enzymes contained in sprouts could be responsible for enhancing the radical scavenging activity $[17,21]$.

Concerning RSA buckwheat flour, Inglett et al. [55] obtained values ranging between $65-71 \%$ RSA, after assessment of four buckwheat flour; and for wheat flour, Han et al. [56] presented a result of $28.0 \pm 5.2 \%$.

\subsection{Final Products Characterization}

\subsubsection{Physico-Chemical Parameters of Buns}

Table 6 presents the following physico-chemical buns parameters: moisture, ash, total fat, protein, fibers and TTA. The analyzes performed on the final baked products showed that buns moisture increases with the augmentation amount of buckwheat added compared to the control buns manufactured only with wheat flour. This could be explained due to the higher fiber content of BW compared to WF, increasing the water absorption capacity of buckwheat flour compared to the wheat. Several authors also reported higher moisture in various bakery products in which buckwheat was added compared to the control sample, attributing this to BW increased water absorption capacity [40-43].

Table 6. Physico-chemical parameters of buns.

\begin{tabular}{|c|c|c|c|c|c|c|}
\hline Sample & $\begin{array}{c}\text { Moisture Content } \\
{[\%]}\end{array}$ & $\begin{array}{l}\text { Ash } \\
{[\%]}\end{array}$ & $\begin{array}{c}\text { Total Fat } \\
{[\%]}\end{array}$ & $\begin{array}{c}\text { Protein } \\
{[\%]}\end{array}$ & $\begin{array}{c}\text { Fibers } \\
{[\%]}\end{array}$ & TTA \\
\hline PM & $39.94 \pm 0.61^{b}$ & $0.56 \pm 0.11^{a}$ & $1.17 \pm 0.22^{a}$ & $7.88 \pm 0.28^{a}$ & $0.69 \pm 0.10^{a}$ & $2.09 \pm 0.15^{a}$ \\
\hline 10BW1 & $42.06 \pm 0.65^{\mathrm{d}}$ & $0.72 \pm 0.25^{b}$ & $1.68 \pm 0.11^{b}$ & $8.51 \pm 0.10^{b}$ & $0.71 \pm 0.14^{\mathrm{a}, \mathrm{b}}$ & $2.53 \pm 0.19^{b, c}$ \\
\hline 20BW1 & $43.76 \pm 0.71^{\mathrm{e}}$ & $0.90 \pm 0.23^{c}$ & $1.83 \pm 0.17^{b, c}$ & $8.63 \pm 0.18^{b}$ & $0.85 \pm 0.11^{\mathrm{d}}$ & $2.83 \pm 0.28^{d}$ \\
\hline 30BW1 & $45.40 \pm 0.52^{f}$ & $1.05 \pm 0.28^{\mathrm{d}}$ & $2.05 \pm 0.15^{c}$ & $8.82 \pm 0.24^{c}$ & $1.15 \pm 0.21^{\mathrm{f}}$ & $3.23 \pm 0.11^{\mathrm{j}, \mathrm{f}}$ \\
\hline 10BW2 & $41.14 \pm 0.53^{c}$ & $0.71 \pm 0.14^{b}$ & $1.74 \pm 0.21^{b}$ & $8.55 \pm 0.31^{b}$ & $0.71 \pm 0.15^{\mathrm{a}, \mathrm{b}}$ & $2.62 \pm 0.18^{c}$ \\
\hline 20BW2 & $43.07 \pm 0.59^{e}$ & $0.89 \pm 0.28^{c}$ & $1.84 \pm 0.11^{b, c}$ & $8.64 \pm 0.29^{b}$ & $0.87 \pm 0.06^{\mathrm{d}}$ & $2.87 \pm 0.13^{d}$ \\
\hline 30BW2 & $44.83 \pm 0.6^{f}$ & $1.02 \pm 0.30^{c, d}$ & $2.04 \pm 0.23^{c}$ & $8.83 \pm 0.25^{c}$ & $1.13 \pm 0.20^{f}$ & $3.25 \pm 0.38^{f}$ \\
\hline 10SF1 & $39.00 \pm 0.54^{a}$ & $1.10 \pm 0.18^{\mathrm{d}}$ & $2.74 \pm 0.28^{\mathrm{d}}$ & $9.03 \pm 0.11^{\mathrm{d}}$ & $0.77 \pm 0.13^{c}$ & $2.45 \pm 0.19^{b}$ \\
\hline 20SF1 & $38.96 \pm 0.48^{a}$ & $1.45 \pm 0.17^{\mathrm{e}}$ & $2.98 \pm 0.25^{\mathrm{d}}$ & $9.26 \pm 0.32 \mathrm{e}$ & $0.96 \pm 0.11^{\mathrm{e}}$ & $2.78 \pm 0.17^{\mathrm{d}}$ \\
\hline 30SF1 & $38.87 \pm 0.39^{a}$ & $1.80 \pm 0.18^{f}$ & $3.92 \pm 0.30^{\mathrm{e}}$ & $9.38 \pm 0.25^{\mathrm{e}}$ & $1.17 \pm 0.14^{f}$ & $3.12 \pm 0.21^{\mathrm{e}}$ \\
\hline 10SF2 & $39.00 \pm 0.42^{a}$ & $1.09 \pm 0.21^{\mathrm{d}}$ & $2.79 \pm 0.25^{\mathrm{d}}$ & $9.08 \pm 0.24^{\mathrm{d}}$ & $0.78 \pm 0.21^{\mathrm{c}}$ & $2.48 \pm 0.27^{b}$ \\
\hline 20SF2 & $38.80 \pm 0.37^{a}$ & $1.40 \pm 0.17^{\mathrm{e}}$ & $3.01 \pm 0.11^{\mathrm{d}}$ & $9.26 \pm 0.34^{\mathrm{e}}$ & $0.97 \pm 0.13^{\mathrm{e}}$ & $2.87 \pm 0.24^{d}$ \\
\hline 30SF2 & $38.72 \pm 0.52^{a}$ & $1.79 \pm 0.21^{\mathrm{f}}$ & $3.84 \pm 0.25^{\mathrm{e}}$ & $9.35 \pm 0.31^{\mathrm{e}}$ & $1.15 \pm 0.16^{f}$ & $3.17 \pm 0.28^{\mathrm{e}, \mathrm{f}}$ \\
\hline
\end{tabular}

PM: control sample; 10BW1, 20BW1, 30BW1: buns with 10\%, 20\%, 30\% buckwheat flour addition and $0.2 \%$ guar gum; 10BW2, 20BW2, 30BW2: buns with 10\%, 20\%, 30\% buckwheat flour and 0.2\% Magimix; 10SF1, 20SF1, 30SF1—buns with $10 \%, 20 \%, 30 \%$ sprouted buckwheat flour and $0.2 \%$ guar gum; 10SF2, 20SF2, 30SF2: buns with 10\%, 20\%, $30 \%$ sprouted buckwheat flour and $0.2 \%$ Magimix. Different lowercase letters within a column indicate significant differences between the means of the same parameter analyzed at $p<0.05$ and $(n=3)$ according to Duncan's multiple range test. All results are expressed to fresh weight (f.w.) product.

On the other side, the addition of sprouted buckwheat flour did not bring any modification of this parameter, the absorption capacity being the same: either $10 \%$ or $30 \%$ of this flour was added. This could be explained due to the higher fat content of SF compared to BW. The fat content of the raw material could have a directly influence on lowering the water absorption capacity, as previously demonstrated by [57].

The highest values for ash and total fat content were registered by buns supplemented with buckwheat sprouts flour followed by the products with addition of buckwheat flour. As we expected, wheat-based products had the lowest levels concerning the ash and total fat content.

The highest fiber content was identified in samples with the addition of SF, followed by samples manufactured with BW. The samples made with WF registered the lower fiber values content. This could be explained by the richest chemical composition of SF fiber $(4.67 \%)$ compared to the BW content $(4.08 \%)$, and WF content $(1.14 \%)$, respectively Table 6 . The use of improver and guar gum did not change in a statistically significant way the final fiber content.

Bhavsar et al. [58] reported for wheat bread $1.98 \%$ fiber content, $2.58 \%$ fiber content for the bread with $10 \%$ buckwheat flour and a value of $3.16 \%$ for the product with $20 \%$ buckwheat flour. These results are higher than those obtained in the present study, probably due to the fiber initial raw materials 
amount. As far as we know, no studies have been found in the literature regarding the content of fiber content in baked goods with the addition of sprouted buckwheat flour.

Regarding the protein content, it changed in all products. It is known that proteins undergo a series of changes during baking, of which the most important is the denaturation of gliadin and glutenins; gluten is transformed from an elastic structure into a semi-rigid one, thereby defining the final shape of the product [59].

The protein content in wheat-based buns (PM) was 7.88\%, meanwhile, the final products supplemented with BW $10 \%, 20 \%$ and $30 \%$ registered values of $8.51 \%, 8.63 \%$ and $8.82 \%$, respectively (Table 6). This could be justified by the higher protein content of BW compared to WF (Table 3). No significant differences were registered between sample with different improvers.

On the other side, the SF use in the manufacture of final baked buns determined an increment of the protein content, as showed in Table 6 This could be explained by the higher protein content of SF compared with BW and WF, respectively (Table 3).

Another parameter that has changed was the TTA, which increased as a result of alcoholic fermentation. The addition of both buckwheat and sprouted buckwheat flour led to the increment of this parameter. Drobot et al. [60] justified the increased TTA value due to the presence of a higher amount of organic acids in buckwheat compared to wheat flour. Selimović et al. [61] and Bojňanská et al. [62] indicated also an augmentation of TTA in bakery products supplemented with buckwheat flour, with positive effects on taste. According to Požrl et al. [46] the increase of TTA causes a decrease of phytic acid content, which is an antinutrient that binds minerals and proteins, changing their solubility, absorption and digestibility. Long fermentation is also associated with quantitative decrease of phytic acid.

\subsubsection{Free Sugars Content of Final Products}

Dough sugars are subjected to transformations during baking, so the temperature gradient between the core and the dough surface is responsible for the behavior of the starch as follows: in the center, being lower temperature, the starch becomes sticky and with a colloidal structure, thus forming the crumb. At the surface, the higher temperature causes dextrinization and caramelization of the available sugars. Volatile gases and compounds are already depleted, and the Maillard reaction between sugars and amino acids leads to the formation of new compounds, responsible for the organoleptic properties typical of the manufactured assortment [63].

The free sugars content of the final baked products increased as BW and SF flour percentages increased due to their richer chemical composition in simple sugars (Table 3) and also as a possible consequence of two reactions: enzymatic hydrolysis of starch and fructans during kneading and fermentation of dough and due to thermal degradation during baking process, which lead to the formation of lower sugars, especially maltose and sucrose [63]. Samples with BW addition registered an augmentation of glucose, sucrose, maltose and fructose content; while in buns supplemented with $\mathrm{SF}$, glucose was reduced, but fructose increased (Table 7).

To the best of our knowledge, no studies have been found in the literature regarding the content of free sugars in baked goods with the addition of these two unconventional flours. 
Table 7. Free sugars content from buns.

\begin{tabular}{ccccc}
\hline Sample & $\begin{array}{c}\text { Glucose } \\
{[\%]}\end{array}$ & $\begin{array}{c}\text { Sucrose } \\
{[\%]}\end{array}$ & $\begin{array}{c}\text { Maltose } \\
{[\%]}\end{array}$ & $\begin{array}{c}\text { Fructose } \\
{[\%]}\end{array}$ \\
\hline RT (min) & 11.20 & 17.80 & 22.70 & 9.10 \\
\hline PM & $0.16 \pm 0.08^{\mathrm{a}}$ & $0.95 \pm 0.10^{\mathrm{a}}$ & $0.83 \pm 0.10^{\mathrm{b}}$ & $0.06 \pm 0.01^{\mathrm{a}}$ \\
10BW1 & $0.16 \pm 0.07^{\mathrm{a}}$ & $0.99 \pm 0.10^{\mathrm{d}}$ & $0.85 \pm 0.12^{\mathrm{b}, \mathrm{c}}$ & $0.08 \pm 0.01^{\mathrm{a}}$ \\
20BW1 & $0.16 \pm 0.08^{\mathrm{a}}$ & $1.04 \pm 0.12^{\mathrm{e}}$ & $0.86 \pm 0.09^{\mathrm{c}}$ & $0.10 \pm 0.01^{\mathrm{a}}$ \\
30BW1 & $0.19 \pm 0.09^{\mathrm{c}}$ & $1.07 \pm 0.08^{\mathrm{f}}$ & $0.89 \pm 0.05^{\mathrm{d}}$ & $0.11 \pm 0.05^{\mathrm{a}}$ \\
10BW2 & $0.16 \pm 0.05^{\mathrm{a}}$ & $0.99 \pm 0.08^{\mathrm{d}}$ & $0.84 \pm 0.07^{\mathrm{b}, \mathrm{c}}$ & $0.08 \pm 0.02^{\mathrm{a}}$ \\
20BW2 & $0.17 \pm 0.05^{\mathrm{b}}$ & $1.04 \pm 0.09^{\mathrm{e}}$ & $0.86 \pm 0.12^{\mathrm{c}}$ & $0.10 \pm 0.03^{\mathrm{a}}$ \\
30BW2 & $0.20 \pm 0.04^{\mathrm{d}}$ & $1.07 \pm 0.06^{\mathrm{f}}$ & $0.89 \pm 0.08^{\mathrm{d}}$ & $0.12 \pm 0.02^{\mathrm{a}}$ \\
10SF1 & $0.16 \pm 0.08^{\mathrm{a}}$ & $0.95 \pm 0.04^{\mathrm{a}}$ & $0.75 \pm 0.05^{\mathrm{a}}$ & $0.23 \pm 0.05^{\mathrm{b}}$ \\
20SF1 & $0.19 \pm 0.05^{\mathrm{c}}$ & $0.95 \pm 0.07^{\mathrm{a}}$ & $0.74 \pm 0.10^{\mathrm{a}}$ & $0.43 \pm 0.05^{\mathrm{c}}$ \\
30SF1 & $0.21 \pm 0.07^{\mathrm{e}}$ & $0.96 \pm 0.06^{\mathrm{a}, \mathrm{b}, \mathrm{c}}$ & $0.73 \pm 0.10^{\mathrm{a}}$ & $0.67 \pm 0.07^{\mathrm{d}}$ \\
10SF2 & $0.17 \pm 0.08^{\mathrm{b}}$ & $0.95 \pm 0.08^{\mathrm{a}, \mathrm{b}}$ & $0.75 \pm 0.07^{\mathrm{a}}$ & $0.23 \pm 0.02^{\mathrm{b}}$ \\
20SF2 & $0.19 \pm 0.01^{\mathrm{c}}$ & $0.96 \pm 0.07^{\mathrm{a}, \mathrm{b}, \mathrm{c}}$ & $0.75 \pm 0.05^{\mathrm{a}}$ & $0.43 \pm 0.08^{\mathrm{c}}$ \\
30SF2 & $0.22 \pm 0.08^{\mathrm{f}}$ & $0.97 \pm 0.10^{\mathrm{c}, \mathrm{d}}$ & $0.73 \pm 0.02^{\mathrm{a}}$ & $0.67 \pm 0.05^{\mathrm{d}}$ \\
\hline
\end{tabular}

RT: Retention time; PM: control sample, 10BW1, 20BW1, 30BW1: buns with 10\%, 20\%, 30\% buckwheat flour addition and $0.2 \%$ guar gum; 10BW2, 20BW2, 30BW2: buns with 10\%, 20\%, 30\% buckwheat flour and $0.2 \%$ Magimix; $10 \mathrm{SF} 1$, 20SF1, 30SF1: buns with 10\%, 20\%, 30\% sprouted buckwheat flour and 0.2\% guar gum; 10SF2, 20SF2, 30SF2: buns with $10 \%, 20 \%, 30 \%$ sprouted buckwheat flour and $0.2 \%$ Magimix. Different lowercase letters within a column indicate significant differences between the means of the same parameter analyzed at $p<0.05$ and $(\mathrm{n}=3)$ according to Duncan's multiple range test.

\subsubsection{Total Flavonoid Content of Buns}

The values resulting from the quantitative determination of the buns total flavonoid are represented graphically in Table 8. The smallest value was obtained for control buns (PM), with a content of $3.99 \mathrm{mg} \mathrm{QE} / 100 \mathrm{~g}$, meanwhile, the highest value was represented by the buns with $30 \%$ sprouts flour $93.97 \mathrm{mg} \mathrm{QE} / 100 \mathrm{~g}$. This could be justified by the highest content in total flavonid of SF, compared to WF (Table 5).

Table 8. Buns' total flavonoids, total phenols and radical scavenging activity.

\begin{tabular}{cccc}
\hline Sample & $\begin{array}{c}\text { Total Flavonoid Content } \\
\text { [mg QE/100 g FW] }\end{array}$ & $\begin{array}{c}\text { Total Polyphenol Content } \\
\text { [mg GAE/100 g FW] }\end{array}$ & $\begin{array}{c}\text { Radical Scavenging Activity } \\
\text { [\%] }\end{array}$ \\
\hline PM & $3.99 \pm 0.12^{\mathrm{a}}$ & $20.33 \pm 0.12^{\mathrm{a}}$ & $35.21 \pm 0.12^{\mathrm{a}}$ \\
10BW1 & $13.99 \pm 0.15^{\mathrm{a}}$ & $36.66 \pm 0.10^{\mathrm{a}, \mathrm{b}}$ & $37.58 \pm 0.15^{\mathrm{b}}$ \\
20BW1 & $30.23 \pm 0.23^{\mathrm{b}}$ & $51.33 \pm 0.26^{\mathrm{b}, \mathrm{c}}$ & $42.87 \pm 0.21^{\mathrm{c}}$ \\
30BW1 & $40.31 \pm 0.25^{\mathrm{b}}$ & $64.66 \pm 0.31^{\mathrm{c}}$ & $46.28 \pm 0.23^{\mathrm{d}}$ \\
10BW2 & $13.98 \pm 0.12^{\mathrm{a}}$ & $36.00 \pm 0.12^{\mathrm{a}, \mathrm{b}}$ & $37.63 \pm 0.19^{\mathrm{b}}$ \\
20BW2 & $30.23 \pm 0.26^{\mathrm{b}}$ & $52.00 \pm 0.18^{\mathrm{b}, \mathrm{c}}$ & $42.90 \pm 0.29^{\mathrm{c}}$ \\
30BW2 & $40.32 \pm 0.21^{\mathrm{b}}$ & $64.33 \pm 0.31^{\mathrm{c}}$ & $46.32 \pm 0.34^{\mathrm{d}}$ \\
10SF1 & $30.98 \pm 0.25^{\mathrm{b}}$ & $48.33 \pm 0.35^{\mathrm{b}, \mathrm{c}}$ & $41.87 \pm 0.21^{\mathrm{c}}$ \\
20SF1 & $63.52 \pm 0.32^{\mathrm{c}}$ & $82.00 \pm 0.51^{\mathrm{d}}$ & $48.99 \pm 0.28^{\mathrm{e}}$ \\
30SF1 & $93.93 \pm 0.39^{\mathrm{d}}$ & $150.33 \pm 0.52^{\mathrm{e}}$ & $54.83 \pm 0.31^{\mathrm{f}}$ \\
10SF2 & $30.97 \pm 0.21^{\mathrm{b}}$ & $49.66 \pm 0.04^{\mathrm{b}, \mathrm{c}}$ & $41.88 \pm 0.15^{\mathrm{c}}$ \\
20SF2 & $63.52 \pm 0.34^{\mathrm{c}}$ & $81.33 \pm 0.56^{\mathrm{d}}$ & $49.09 \pm 0.25^{\mathrm{e}}$ \\
30SF2 & $93.94 \pm 0.41^{\mathrm{d}}$ & $151.00 \pm 0.48^{\mathrm{e}}$ & $54.96 \pm 0.36^{\mathrm{f}}$ \\
\hline
\end{tabular}

f.w.: fresh weight; PM: control sample; 10BW1, 20BW1, 30BW1: buns with 10\%, 20\%, 30\% buckwheat flour addition and $0.2 \%$ guar gum; 10BW2, 20BW2, 30BW2: buns with 10\%, 20\%, 30\% buckwheat flour and $0.2 \%$ Magimix; $10 \mathrm{SF} 1$, 20SF1, 30SF1: buns with 10\%, 20\%, 30\% sprouted buckwheat flour and 0.2\% guar gum; 10SF2, 20SF2, 30SF2: buns with 10\%, 20\%, 30\% sprouted buckwheat flour and 0.2\% Magimix. Different lowercase letters within a column indicate significant differences between the means of the same parameter analyzed at $p<0.05$ and $(\mathrm{n}=3)$ according to Duncan's multiple range test.

According to Chlopicka et al. [64], the flavonoid content decreases 2-4 times in the final bakery products compared to the flour. In their study, wheat-based buns had a $2.03 \mathrm{mg} / 100 \mathrm{~g}$ total flavonoid content; product with $15 \%$ buckwheat flour obtained $3.34 \mathrm{mg} / 100 \mathrm{~g}$ total flavonoids and, surprisingly, buns with $30 \%$ buckwheat had a score of $3.29 \mathrm{mg} / 100 \mathrm{~g}$. 
Constantini et al. [65] obtained similar, lower values for the final baked products correlated to the raw material, so for bread from $100 \%$ wheat flour total flavonoid content was $60 \pm 20 \mathrm{mg} \mathrm{RE} / 100 \mathrm{~g}$, while for wheat flour this value was higher $-80 \pm 5 \mathrm{mg}$ RE/100 $\mathrm{g}$ (RE: rutin).

\subsubsection{Total Phenolic Content of Final Products}

The content of polyphenols is closely related to the antioxidant capacity; baking causes partial loss of polyphenols and therefore of the antioxidant capacity [56,60]. According to Selimović et al. [61] and Chlopicka et al. [64] values of total polyphenols in baked products are lower than in flour and dough.

The lowest result obtained in this research was for the control sample-20.33 mg GAE/100 g (Table 8) which is in accordance with the value reported by Alvarez-Jubete et al. [7] (29.1 $\pm 0.6 \mathrm{mg} \mathrm{GAE} / 100 \mathrm{~g})$.

The addition of $10 \%, 20 \%$ and $30 \%$ SF increased the total phenolic content by 2.37 (48.33 mg GAE/100 g), 4.03 (82 mg GAE/100 g) and 7.39 (150.33 mg GAE/100 g) times compared to wheat-based products. Total phenols content of the samples supplemented with BW were higher compared to the product based on wheat flour, but lower than the SF final baked products (Table 8). This could be explained through the chemical composition of SF which was higher in total phenols content compared to BW (Table 5). No significant difference $(p<0.05)$ in total phenols content were found between samples with guar gum and improver, respectively.

The current state of art regarding the phenolic content in bakery products manufactured with BW, reported different values for total phenolic content. For instance, Selimović et al. [61] obtained a value of $12 \pm 24 \mathrm{mg} \mathrm{GAE} / 100 \mathrm{~g}$ for control, $25 \pm 31 \mathrm{mg} \mathrm{GAE} / 100 \mathrm{~g}$ for products with $15 \%$ buckwheat flour and $46 \pm 62 \mathrm{mg} \mathrm{GAE} / 100 \mathrm{~g}$ for bread with $30 \%$ buckwheat.

In the study carried out by Chlopicka et al. [64] the total phenolic compounds were $1.7 \pm 0.07 \mathrm{mg} \mathrm{GAE} / \mathrm{g}$ for the control sample, $2.1 \pm 0.08 \mathrm{mg} \mathrm{GAE} / \mathrm{g}$ for bread with $15 \%$ buckwheat and $2.65 \pm 0.1 \mathrm{mg} \mathrm{GAE} / \mathrm{g}$ product with $30 \%$ buckwheat.

To the best of our knowledge, regarding the determination of total polyphenolic content for the bakery products fortified with SF, no reports were found.

\subsubsection{Radical Scavenging Activity of Samples}

Buns with the addition of SF have a higher radical scavenging activity (10SF1-41.87\%, 20SF1-48.99\%, 30SF1-54.83\%) than products manufactured with buckwheat flour (10BW1-37.58\%, 20BW1-42.87\%, 30BW1-46.28\%), respectively those with wheat flour (35.21\%). Between the samples with $0.2 \%$ guar and those with $0.2 \%$ improver not significant differences $(p<0.05)$ were noticed (Table 8 ).

There are many researches which show that baking process causes a decrease of antioxidant capacity baked goods [64,66-68]. The addition of different flours with a rich antioxidant activity might be able to enhance the antioxidant capacity of the final baked goods or to minimize its thermal losses [64,68,69].

According to the literature there are also studies that showed an increase in the radical scavenging capacity of wheat-based products compared to flour and dough as a result of the conjugated phenolic compounds release, especially in crust. Moreover, these works attribute this increase in antioxidant capacity to the Maillard reaction too [56,68].

\subsubsection{Rheological Evaluation of Products}

In the present study, the following textural parameters have been analyzed: total work, hardness, cohesiveness, springiness, chewiness, gumminess and adhesiveness, as listed in Table 9. 
Table 9. Textural analysis of baked products.

\begin{tabular}{|c|c|c|c|c|c|c|c|c|c|}
\hline Sample & $\begin{array}{c}\text { Total Work Cycle } 1 \\
{[\mathrm{~mJ}]}\end{array}$ & $\begin{array}{c}\text { Hardness Cycle } 1 \\
{[\mathrm{~g}]}\end{array}$ & $\begin{array}{c}\text { Total Work Cycle } 2 \\
{[\mathrm{~mJ}]}\end{array}$ & $\begin{array}{c}\text { Hardness Cycle } 2 \\
{[\mathrm{~g}]}\end{array}$ & $\begin{array}{c}\text { Cohesiveness } \\
\text { [n.a.] }\end{array}$ & $\begin{array}{c}\text { Springiness } \\
\text { [n.a.] }\end{array}$ & $\begin{array}{c}\text { Chewiness } \\
{[\mathrm{g}]}\end{array}$ & $\begin{array}{c}\text { Gumminess } \\
{[\mathrm{g}]}\end{array}$ & $\begin{array}{c}\text { Adhesiveness } \\
\text { [g] }\end{array}$ \\
\hline PM & $33.90 \pm 0.65^{f}$ & $482.00 \pm 2.58^{c}$ & $28.97 \pm 0.21^{\mathrm{b}, c, \mathrm{~d}}$ & $463.00 \pm 2.11^{b, c}$ & $0.81 \pm 0.11^{\mathrm{e}, \mathrm{f}}$ & $1.22 \pm 0.21 \mathrm{~g}$ & $407.67 \pm 2.33^{c}$ & $398.67 \pm 2.15^{b}$ & $3.00 \pm 0.12^{b, c}$ \\
\hline 10BW1 & $29.63 \pm 0.34^{d}$ & $353.00 \pm 1.99 \mathrm{~b}$ & $29.23 \pm 0.19 \mathrm{~b}, \mathrm{c}, \mathrm{d}$ & $477.33 \pm 2.65^{c}$ & $0.85 \pm 0.10^{g}$ & $0.95 \pm 0.17^{f}$ & $411.67 \pm 2.57^{c}$ & $430.67 \pm 2.18^{b}$ & $3.00 \pm 0.10^{b, c}$ \\
\hline 20BW1 & $31.13 \pm 0.35^{\mathrm{e}}$ & $393.00 \pm 2.65^{\mathrm{b}}$ & $34.90 \pm 0.25^{\mathrm{c}, \mathrm{d}}$ & $588.00 \pm 2.49^{d}$ & $0.83 \pm 0.21^{\mathrm{f}, \mathrm{g}}$ & $0.95 \pm 0.11^{\mathrm{f}}$ & $495.33 \pm 2.56^{\mathrm{c}}$ & $505.00 \pm 1.95^{\mathrm{c}}$ & $5.67 \pm 0.15^{\mathrm{e}}$ \\
\hline 30BW1 & $34.43 \pm 0.28^{f}$ & $526.00 \pm 2.24^{\mathrm{d}}$ & $38.60 \pm 0.31^{\mathrm{d}}$ & $623.33 \pm 3.10^{\mathrm{d}}$ & $0.85 \pm 0.18^{\mathrm{g}}$ & $0.94 \pm 0.13^{f}$ & $526 \pm 3.11^{\mathrm{d}}$ & $537.00 \pm 2.12^{c}$ & $8.67 \pm 0.21^{\mathrm{f}}$ \\
\hline 10BW2 & $15.37 \pm 0.21^{\mathrm{a}}$ & $508.60 \pm 2.18^{\mathrm{c}, \mathrm{d}}$ & $30.53 \pm 0.29^{b, c, d}$ & $486.33 \pm 2.00^{\mathrm{c}}$ & $0.79 \pm 0.25^{\mathrm{e}}$ & $0.86 \pm 0.21^{b, c}$ & $237.33 \pm 2.01^{\mathrm{a}}$ & $400.67 \pm 2.85^{b}$ & $2.67 \pm 0.18^{a, b}$ \\
\hline 20BW2 & $22.00 \pm 0.19^{b}$ & $346.67 \pm 2.59^{b}$ & $18.97 \pm 0.17 \mathrm{a}, \mathrm{b}$ & $298.33 \pm 1.85^{\mathrm{a}}$ & $0.76 \pm 0.17^{\mathrm{d}}$ & $0.83 \pm 0.18^{\mathrm{a}, \mathrm{b}}$ & $280.33 \pm 2.15^{\mathrm{a}, \mathrm{b}}$ & $527.33 \pm 2.68^{c}$ & $3.67 \pm 0.17^{\mathrm{c}, \mathrm{d}}$ \\
\hline 30BW2 & $18.30 \pm 0.20^{\mathrm{b}}$ & $251.65 \pm 1.85^{\mathrm{a}}$ & $13.20 \pm 0.15^{a}$ & $243.00 \pm 1.19^{\mathrm{a}}$ & $0.75 \pm 0.31^{c, d}$ & $0.80 \pm 0.20^{\mathrm{a}}$ & $422.67 \pm 3.08^{c}$ & $576.33 \pm 2.75^{c}$ & $4.33 \pm 0.14^{\mathrm{d}}$ \\
\hline 10SF1 & $26.40 \pm 0.25^{c}$ & $385.00 \pm 2.10^{b}$ & $21.87 \pm 0.22 \mathrm{a}, \mathrm{b}$ & $367.67 \pm 2.25^{b}$ & $0.80 \pm 0.22 \mathrm{e}$ & $0.93 \pm 0.11^{\mathrm{e}, \mathrm{f}}$ & $286.00 \pm 2.54^{\mathrm{a}, \mathrm{b}}$ & $306.67 \pm 13.68^{\mathrm{a}}$ & $2.33 \pm 0.10^{\mathrm{a}}$ \\
\hline 20SF1 & $83.30 \pm 1.02^{\mathrm{h}}$ & $1379.33 \pm 5.25^{f}$ & $67.50 \pm 0.63^{\mathrm{e}}$ & $1176.00 \pm 3.87^{\mathrm{e}}$ & $0.76 \pm 0.15^{\mathrm{d}}$ & $0.91 \pm 0.14 \mathrm{~d}, \mathrm{e}, \mathrm{f}$ & $830.00 \pm 2.98^{\mathrm{e}}$ & $949.33 \pm 3.11^{\mathrm{d}}$ & $2.67 \pm 0.18^{a, b}$ \\
\hline 30SF1 & $101.47 \pm 1.29^{\mathrm{i}}$ & $2407.00 \pm 6.29 \mathrm{~h}$ & $115.90 \pm 0.76^{\mathrm{g}}$ & $2408.00 \pm 4.85^{\mathrm{f}}$ & $0.73 \pm 0.18^{c}$ & $0.89 \pm 0.10 \mathrm{c}, \mathrm{d}, \mathrm{e}$ & $1317.33 \pm 3.98^{f}$ & $1632.67 \pm 4.02^{f}$ & $4.00 \pm 0.22^{\mathrm{d}}$ \\
\hline 10SF2 & $28.17 \pm 0.25^{\mathrm{d}}$ & $404.00 \pm 2.15^{b, c}$ & $22.60 \pm 0.23 \mathrm{a}, \mathrm{b}, \mathrm{c}$ & $376.33 \pm 1.42^{b}$ & $0.70 \pm 0.12^{b}$ & $0.87 \pm 0.18^{b, c, d}$ & $279.00 \pm 2.11^{\mathrm{a}, \mathrm{b}}$ & $301.33 \pm 2.68^{\mathrm{a}}$ & $3.67 \pm 0.17^{\mathrm{c}, \mathrm{d}}$ \\
\hline 20SF2 & $79.77 \pm 1.00 \mathrm{~g}$ & $950.67 \pm 2.21 \mathrm{e}$ & $39.50 \pm 0.35^{\mathrm{d}}$ & $658.00 \pm 2.85^{\mathrm{d}}$ & $0.68 \pm 0.13^{b}$ & $0.85 \pm 0.11^{b, c}$ & $705.00 \pm 2.54 \mathrm{e}$ & $839.00 \pm 3.11^{\mathrm{d}}$ & $3.67 \pm 0.11^{\mathrm{c}, \mathrm{d}}$ \\
\hline 30SF2 & $109.77 \pm 1.19^{j}$ & $1907.00 \pm 4.25 \mathrm{~g}$ & $82.60 \pm 0.68^{f}$ & $1167.33 \pm 3.86^{\mathrm{e}}$ & $0.65 \pm 0.14^{\mathrm{a}}$ & $0.79 \pm 0.19^{\mathrm{a}}$ & $1235.00 \pm 3.02^{f}$ & $1418.00 \pm 3.00^{\mathrm{e}}$ & $3.33 \pm 0.26^{\mathrm{c}, \mathrm{d}}$ \\
\hline
\end{tabular}

PM: control sample; 10BW1, 20BW1, 30BW1: buns with 10\%, 20\%, 30\% buckwheat flour addition and 0.2\% guar gum; 10BW2, 20BW2, 30BW2: buns with 10\%, 20\%, 30\% buckwheat flour and $0.2 \%$ Magimix; 10SF1, 20SF1, 30SF1: buns with 10\%, 20\%, 30\% sprouted buckwheat flour and $0.2 \%$ guar gum; $10 \mathrm{SF} 2,20 \mathrm{SF} 2,30 \mathrm{SF} 2$ : buns with $10 \%$, 20\%, 30\% sprouted buckwheat flour and $0.2 \%$ Magimix. Different lowercase letters within a column indicate significant differences between the means of the same parameter analyzed at $p<0.05$ and ( $\mathrm{n}=3$ ) according to Duncan's multiple range test. 
The principal mechanical characteristic of solid foods is represented by hardness [70]. This parameter is defined as the force needed to obtain a given deformation of the product [36]. In the present study, hardness 1 and 2 values increased as the percentage of buckwheat flour increased. The same pattern was observed on the final baked products manufactured with different percentages of SF flour. The explanation for the hardness 1 and 2 increased values could be the reduction of gluten content matrix, considering that BW and SF flours are gluten free. This is in line with Man et al. [43], who reported that the dough reduction in gluten matrix could lead to a harder bread texture. Furthermore, Moradi et al. [71] showed that gluten matrix is also involved in the elasticity of the dough and its capacity to retain gases during fermentation process, having a key role in bakery foods manufacture.

On the other side, the use of guar gum and Magimix improver, lead to significantly different values for hardness 1 and 2 (Table 9). For instance, for hardness 2, the samples manufactured with Magimix registered lower values, than those made with guar gum. This could be due to the chemical composition of Magimix, mainly to alpha-amylase content which could be involved in the improvement of dough properties. In this light, Savkina et al. [72] reported that improvers with alpha-amylase could enhanced bread texture and elasticity. Moreover, it is important to mentioned that Magimix contains also xylanase, which positively influenced the bread hardness, as reported by Shah et al., [73]. Likewise, Rodge et al. [27] proved that guar gum had no significant influence on the crust of the white bread, therefore, its hardness. The chewiness and gumminess parameters, showed proportional trends with hardness, samples with $0.2 \%$ guar registered higher values than samples with $0.2 \%$ improver.

On the other hand, regarding the cohesiveness, a parameter used to describe the internal cohesion of the material [36], the products manufactured with guar gum, showed better results. Cohesiveness value is desirable to reach a high value because it helps to form a bolus during mastication process, instead of disintegration of the product [74]. This is in concordance with Encina-Zelada et al. [74] who demonstrated that gum improved cohesiveness even in the gluten free products. In the same light, Turkut et al. [75] proved that the moisture content of the final baked goods could be involved in lowering cohesiveness and chewiness values. In the present study, the moisture content of the buns manufactured with different percentages of BW changed, reaching higher value when 30\% BW was added, meanwhile in SF final baked goods no statistical differences were noticed (Table 6).

Springiness is a textural parameter linked to freshness and elasticity of the final baked products [75] and therefore is desirable to have high values. Samples with guar gum registered higher values that those with improver (Table 4). Rodge et al. [27] demonstrated that guar gum could improve dough stability and could enhance the elasticity of the final baked product.

Adhesiveness is defined as the necessary force needed to remove the product to the palate with tongue help [76]. In the present study, the adhesiveness of the final baked products made with guar gum were statistically different that those made with improver. This could be explained by the capacity of guar gum to have a positive influence on the dough stickiness, as reported by Ghodke, [77].

\subsubsection{Sensorial Analysis}

The final baked products manufactured with BW flour were more appreciated by panelists than those made with SF flour (Table 10). From the sensorial point of view, 20BW1and 10SF1 buns were the most appreciated by the panelists, reaching a final hedonic score of 9.1 and 8.7 respectively. This is in agreement with Starowicz et al. [78] who reported that the use of buckwheat flour in a range of 20-30\% in bakery products manufacture reached the highest sensory acceptance. Bilgiçli \& İbanoğlu [79] stated that breads produced with $10 \%$ and $20 \%$ buckwheat flour have been shown to have acceptable sensory qualities. 
Table 10. Hedonic scores for buns.

\begin{tabular}{|c|c|c|c|c|c|c|}
\hline Sample & Visual Appearance & Texture & Odor & Taste & Flavor & $\begin{array}{c}\text { Overall } \\
\text { Acceptability }\end{array}$ \\
\hline PM & $9.10 \pm 0.15^{g}$ & $9.00 \pm 0.21^{\mathrm{f}}$ & $9.00 \pm 0.15^{f}$ & $9.00 \pm 0.18^{g}$ & $9.10 \pm 0.10^{d}$ & $9.20 \pm 0.14^{\mathrm{g}}$ \\
\hline 10BW1 & $9.00 \pm 0.21^{\mathrm{f}, \mathrm{g}}$ & $8.60 \pm 0.32 \mathrm{~d}, \mathrm{e}, \mathrm{f}$ & $9.00 \pm 0.25^{\mathrm{f}}$ & $9.00 \pm 0.14 \mathrm{~g}$ & $9.00 \pm 0.10^{d}$ & $8.90 \pm 0.12^{f, g}$ \\
\hline 20BW1 & $9.10 \pm 0.10^{g}$ & $8.90 \pm 0.25^{f}$ & $9.00 \pm 0.15^{\mathrm{f}}$ & $9.10 \pm 0.10^{g}$ & $9.10 \pm 0.12^{\mathrm{d}}$ & $9.30 \pm 0.10 \mathrm{~g}$ \\
\hline 30BW1 & $7.10 \pm 0.21^{b}$ & $5.90 \pm 0.17^{\mathrm{b}}$ & $6.70 \pm 0.32^{b}$ & $6.50 \pm 0.35^{\mathrm{a}, \mathrm{c}}$ & $6.20 \pm 0.45^{\mathrm{a}}$ & $7.00 \pm 0.42^{c}$ \\
\hline 10BW2 & $8.60 \pm 0.17^{\mathrm{d}, \mathrm{e}, \mathrm{f}}$ & $8.50 \pm 0.23^{\mathrm{d}, \mathrm{e}, \mathrm{f}}$ & $8.30 \pm 0.25^{\mathrm{d}, \mathrm{e}}$ & $8.20 \pm 0.24^{\mathrm{e}}$ & $8.70 \pm 0.25^{c, d}$ & $8.90 \pm 0.22^{f, g}$ \\
\hline 20BW2 & $8.50 \pm 0.28^{\mathrm{d}, \mathrm{e}}$ & $8.30 \pm 0.24 \mathrm{~d}, \mathrm{e}$ & $8.20 \pm 0.15^{\mathrm{d}, \mathrm{e}}$ & $8.30 \pm 0.23 \mathrm{e}, \mathrm{f}$ & $8.50 \pm 0.11^{c, d}$ & $8.50 \pm 0.25^{\mathrm{e}, \mathrm{f}}$ \\
\hline 30BW2 & $6.80 \pm 0.30^{\mathrm{b}}$ & $5.60 \pm 0.52^{\mathrm{a}, \mathrm{b}}$ & $6.20 \pm 0.29^{a}$ & $6.20 \pm 0.29^{a, b, c}$ & $5.80 \pm 0.19^{\mathrm{a}}$ & $6.00 \pm 0.36^{\mathrm{a}}$ \\
\hline 10SF1 & $8.70 \pm 0.45^{\mathrm{f}}$ & $8.90 \pm 0.20^{f}$ & $8.90 \pm 0.18^{f}$ & $8.80 \pm 0.11 \mathrm{~g}$ & $8.90 \pm 0.45^{\mathrm{d}}$ & $9.20 \pm 0.32 \mathrm{~g}$ \\
\hline 20SF1 & $8.90 \pm 0.25^{\mathrm{e}, \mathrm{f}, \mathrm{g}}$ & $8.70 \pm 0.17^{\mathrm{e}}$ & $8.60 \pm 0.18^{\mathrm{e}, \mathrm{f}}$ & $8.70 \pm 0.17^{\mathrm{f}, \mathrm{g}}$ & $8.60 \pm 0.11^{c, d}$ & $8.60 \pm 0.25^{\mathrm{e}, \mathrm{f}}$ \\
\hline 30SF1 & $6.70 \pm 0.32^{b}$ & $5.50 \pm 0.36^{\mathrm{a}, \mathrm{b}}$ & $6.30 \pm 0.34^{\mathrm{a}, \mathrm{b}}$ & $6.00 \pm 0.35^{\mathrm{a}}$ & $6.00 \pm 0.25^{a}$ & $6.50 \pm 0.11^{b}$ \\
\hline 10SF2 & $8.30 \pm 0.38^{c, d}$ & $8.00 \pm 0.30^{c, d}$ & $7.90 \pm 0.25^{c, d}$ & $8.00 \pm 0.21 \mathrm{~d}, \mathrm{e}$ & $8.30 \pm 0.16^{b, c}$ & $8.10 \pm 0.15^{\mathrm{d}, \mathrm{e}}$ \\
\hline 20SF2 & $7.90 \pm 0.22^{c}$ & $7.60 \pm 0.17^{c}$ & $7.60 \pm 0.52^{c}$ & $7.70 \pm 0.28^{\mathrm{d}}$ & $7.90 \pm 0.32^{b}$ & $7.80 \pm 0.46^{\mathrm{d}}$ \\
\hline 30SF2 & $6.00 \pm 0.15^{a}$ & $5.00 \pm 0.50^{\mathrm{a}}$ & $6.00 \pm 0.21^{\mathrm{a}}$ & $6.00 \pm 0.45^{a, b}$ & $6.00 \pm 0.50^{\mathrm{a}}$ & $5.70 \pm 0.50^{\mathrm{a}}$ \\
\hline
\end{tabular}

PM: control sample; 10BW1, 20BW1, 30BW1: buns with 10\%, 20\%, 30\% buckwheat flour addition and $0.2 \%$ guar gum; 10BW2, 20BW2, 30BW2: buns with 10\%, 20\%, 30\% buckwheat flour and 0.2\% Magimix; 10SF1, 20SF1, 30SF1: buns with $10 \%, 20 \%, 30 \%$ sprouted buckwheat flour and $0.2 \%$ guar gum; 10SF2, 20SF2, 30SF2: buns with 10\%, 20\%, $30 \%$ sprouted buckwheat flour and $0.2 \%$ Magimix. Different lowercase letters within a column indicate significant differences between the means of the same parameter analyzed at $p<0.05$ and $(n=3)$ according to Duncan's multiple range test.

The consumers' preference through the products with buckwheat flour could be justified by their better taste, structure and color, compared to those with SF. This is in line with $\mathrm{Xu}$ at al. 2014, who reported that $12 \% \mathrm{SF}$ addition could produce remarkable negative impact on the textural and sensorial properties of bread. Besides, the color of the products made with BW flour became less darker (Figure 1), compared with the buns manufactured with SF flour (Figure 2).

On the other hand, the use of guar gum in the manufactured of baked products could have a positive influence on sensorial features such as taste and color [71,78]. The positive influence of the guar gum on the final color of the bakery products is confirmed also by Rodge et al. [27] who reported that the polysaccharides for the guar gum could be involved in the Maillard reaction and influencing the intensity of the brown color.

Due to the germination process, the amount of alpha-amylase increased favoring the hydrolysis of starch and enhancing the dextrin level during baking process. These enzymes in a higher amount could lead to sticky final baked products with a low satiety value, according to $\mathrm{Xu}$ et al. [80]. Moreover, buckwheat sprouts have a bitter and astringent taste due to their high-level content of flavonoids, causing at high level percentages the product's consumer unacceptability [80]. 


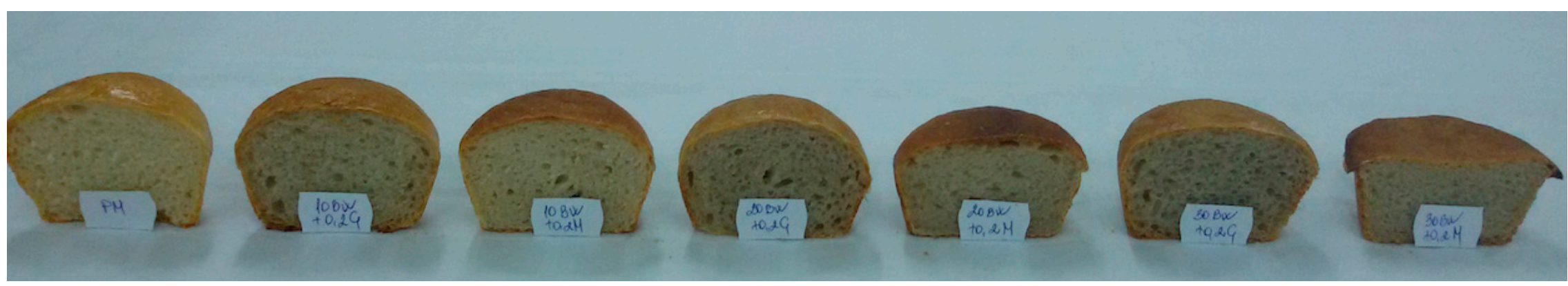

Figure 1. Buns with addition of buckwheat flour and $0.2 \%$ guar gum, $0.2 \%$ baking improver, respectively and sections of the obtained final baked buns. PM: control sample; 10BW1: buns with 10\% buckwheat flour addition and 0.2\% guar gum; 20BW1: buns with 20\% buckwheat flour addition and 0.2\% guar gum; 30BW1: buns with 30\% buckwheat flour addition and 0.2\% guar gum; 10BW2: buns with 10\% buckwheat flour addition and 0.2\% Magimix; 20BW2: buns with 20\% buckwheat flour addition and 0.2\% Magimix; 30BW2-buns with 30\% buckwheat flour addition and $0.2 \%$ Magimix.

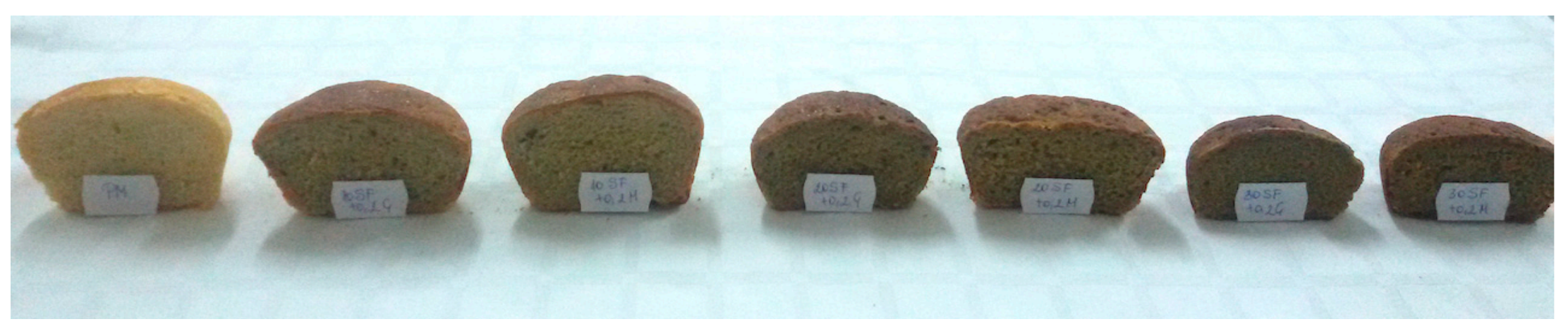

Figure 2. Buns with addition of sprouted buckwheat flour and $0.2 \%$ guar gum, $0.2 \%$ baking improver, respectively and sections of the obtained final baked buns. PM: control sample; 10SF1: buns with 10\%, sprouted buckwheat flour and $0.2 \%$ guar gum; 20SF1: buns with 20\%, sprouted buckwheat flour and 0.2\% guar gum; 30SF1: buns with $30 \%$, sprouted buckwheat flour and $0.2 \%$ guar gum; 10SF2: buns with 10\%, sprouted buckwheat flour and $0.2 \%$ Magimix; 20SF2: buns with 20\%, sprouted buckwheat flour and 0.2\% Magimix; 30SF2: buns with 30\%, sprouted buckwheat flour and 0.2\% Magimix. 


\section{Conclusions}

Buckwheat and sprouts buckwheat flours are valuable raw materials, which had a serious impact on the nutritional enrichment on the final baked products. For instance, the use of 10SF and 20BW composite flours increased the total flavonoids content of the final baked products with $26.24 \%$ and $26.99 \%$ respectively. The same trend was observed at total phenols where 10SF1 was 2.37 times higher than the control sample, meanwhile 20BW1 was 2.52 times higher. In the same light, radical scavenging activity of 10SF1 and 20BW1 increased compared to the control with $6.66 \%$ and $7.66 \%$ respectively.

Furthermore, there uses in buns manufacturing are limited due to their negative influence on the sensorial and rheological features. The sensorial analysis showed that samples manufactured with $20 \%$ buckwheat flour and guar gum and buns made with $10 \%$ sprouts buckwheat flour with guar gum were the most appreciated final baked goods regarding the following parameters: overall appearance, taste, flavor, odor, color and texture, reaching a final hedonic score of 9.3 and 9.2, respectively.

With respect to rheological features, it is necessary the assessment of further rheological parameters to have broader understanding how these additives could influence the texture of the final baked products.

To conclude, we can assess that buckwheat and sprouts buckwheat flours are precious raw materials that could be successfully used for the improvement of bakery products nutritional values.

Author Contributions: Conceptualization, A.S. and S.M.; methodology, D.C.V., S.M.M., M.S.C. and A.P.; software, A.C.U. and A.S.; validation, A.S., M.S.C., D.C.V. and A.P.; formal analysis, M.S.C., A.C.U., V.M., G.F. and I.E.R.; writing — original draft preparation, A.S., M.S.C. and A.P.; writing-review and editing, A.S. and M.S.C.; supervision, S.M.; project administration, A.S. and S.M. All authors have read and agreed to the published version of the manuscript.

Funding: This research publication was supported by funds from the Ministry of Education and Research (FDI 0252).

Acknowledgments: The authors acknowledge the technical support provided by the researcher Laura Stan and by the researcher Orsolya Borsai.

Conflicts of Interest: The authors declare no conflict of interest.

\section{References}

1. Shahidi, F.; Chandrasekara, A. Millet grain phenolics and their role in disease risk reduction and health promotion: A review. J. Funct. Foods 2013, 5, 570-581. [CrossRef]

2. Dapčević-Hadnađev, T.; Torbica, A.; Hadnađev, M. Rheological properties of wheat flour substitutes/alternative crops assessed by Mixolab. Procedia Food Sci. 2011, 1, 328-334. [CrossRef]

3. Giacco, R.; Clemente, G.; Cipriano, D.; Luongo, D.; Viscovo, D.; Patti, L.; Di Marino, L.; Giacco, A.; Naviglio, D.; Bianchi, M.; et al. Effects of the regular consumption of wholemeal wheat foods on cardiovascular risk factors in healthy people. Nutr. Metab. Cardiovasc. Dis. 2010, 20, 186-194. [CrossRef] [PubMed]

4. Dziki, D.; Różyło, R.; Gawlik-Dziki, U.; Świeca, M. Current trends in the enhancement of antioxidant activity of wheat bread by the addition of plant materials rich in phenolic compounds. Trends Food Sci. Technol. 2014, 40, 48-61. [CrossRef]

5. Stamatovska, V.; Nakov, G.; Uzunoska, Z.; Kalevska, T.; Menkinoska, M. Potential use of some pseudocereals in the food industry. ARTTE 2018, 6, 54-61. [CrossRef]

6. Alvarez-Jubete, L.; Arendt, E.K.; Gallagher, E. Nutritive value and chemical composition of pseudocereals as gluten-free ingredients. Int. J. Food Sci. Nutr. 2009, 60, 240-257. [CrossRef]

7. Alvarez-Jubete, L.; Wijngaard, H.; Arendt, E.K.; Gallagher, E. Polyphenol composition and in vitro antioxidant activity of amaranth, quinoa buckwheat and wheat as affected by sprouting and baking. Food Chem. 2010, 119, 770-778. [CrossRef]

8. Păucean, A. Tendințe Moderne Privind Cresterea Valorii Nutritive a Făinii de Grâu Și a Produselor de Panificație; Editura MEGA: Cluj-Napoca, Romania, 2017; p. 39.

9. Mir, N.A.; Riar, C.S.; Singh, S. Nutritional constituents of pseudo cereals and their potential use in food systems: A review. Trends Food Sci. Technol. 2018, 75, 170-180. [CrossRef] 
10. Khan, F.; Arif, M.; Khan, T.U.; Khan, M.I.; Bangash, J.A. Nutritional evaluation of common buckwheat of four different villages of gilgit-baltisan. ARPN J. Agric. Biol. Sci. 2013, 8, 264-266.

11. Golob, A.; Stibilj, V.; Kreft, I.; Germ, M. The feasibility of using tartary buckwheat as a se-containing food material. J. Chem. 2015, 2015, 246042. [CrossRef]

12. Fabjan, N.; Rode, J.; Košir, I.J.; Wang, Z.; Zhang, Z.; Kreft, I. Tartary buckwheat (Fagopyrum tataricum Gaertn.) as a source of dietary rutin and quercitin. J. Agric. Food Chem. 2003, 51, 6452-6455. [CrossRef]

13. Brennan, C.S. Dietary fibre, glycaemic response, and diabetes. Mol. Nutr. Food Res. 2005, 49, 560-570. [CrossRef]

14. Békés, F.; Schoenlechner, R.; Tömösközi, S. Chapter 14-Ancient Wheats and Pseudocereals for Possible Use in Cereal-Grain Dietary Intolerances. In Cereal Grains 2nd Edition Assessing and Managing Quality; Wrigley, C., Batey, I., Miskelly, D., Eds.; Woodhead Publishing: Cambridge, UK, 2017; pp. 353-389.

15. Wijngaard, H.H.; Arendt, E.K. Buckwheat-Review. Cereal Chem. 2006, 83, 391-401. [CrossRef]

16. Frutos, M.J.; Rincón-Frutos, L.; Valero-Cases, E. Chapter 2.14-Rutin, Nonvitamin and Nonmineral Nutritional Supplements; Academic Press: London, UK, 2019; pp. 111-117.

17. Brajdes, C.; Vizireanu, C. Sprouted buckwheat an important vegetable source of antioxidants. Ann. Univ. Dunarea Jos Galati Fascicle VI Food Technol. 2012, 36, 53-60.

18. Márton, M.; Mándoki, Z.; Csapó-Kiss, Z.; Csapó, J. The role of sprouts in human nutrition. A review. Aliment. Hung. Univ. Transylvania 2010, 3, 81-117.

19. Schendel, R. Chapter 10-Phenol content in sprouted grains. In Sprouted Grains Nutritional Value, Production and Applications; Feng, H., Nemzer, B., DeVries, J.W., Eds.; Woodhead Publishing: Duxford, UK, 2019; pp. 247-316.

20. Nemzer, B.; Lin, Y.; Huang, D. Chapter 3-Antioxidants in sprouts of grains. In Sprouted Grains Nutritional Value, Production and Applications; Feng, H., Nemzer, B., DeVries, J.W., Eds.; Woodhead Publishing: Duxford, UK, 2019; pp. 55-68.

21. Zhang, G.; Xu, Z.; Gao, Y.; Huang, X.; Zou, Y.; Yang, T. Effects of germination on the nutritional properties, phenolic profiles, and antioxidant activities of buckwheat. J. Food Sci. 2015, 80, H1111-H1119. [CrossRef] [PubMed]

22. Mir, S.A.; Shah, M.A.; Naik, H.R.; Zargar, I.A. Influence of hydrocolloids on dough handling and technological properties of gluten-free breads. Trends Food Sci. Technol. 2016, 51, 49-57. [CrossRef]

23. Li, J.-M.; Nie, S.-P. The functional and nutritional aspects of hydrocolloids in foods. Food Hydrocoll. 2016, 53, 46-61. [CrossRef]

24. Gupta, S.; Variyar, P. Chapter 12-Guar Gum: A Versatile Polymer for the Food Industry. In Biopolymers for Food Design; Grumezescu, A.M., Holban, A.M., Eds.; Academic Press: London, UK, 2018; Volume 20, pp. 487-514.

25. Thombare, N.; Jha, U.; Mishara, S.; Siddiqui, M.Z. Guar gum as a promissing starting material for diverse applications: A review. Int. J. Biol. Macromol. 2016, 88, 361-372. [CrossRef] [PubMed]

26. BeMiller, J.N. Chapter 9-Guar, Locust Bean, Tara and Cassia Gums. In Carbohydrate Chemistry for Food Scientists, 3rd ed.; Academic Press: West Lafayette, IN, USA, 2018; pp. 241-252.

27. Rodge, A.B.; Sonkamble, S.M.; Salve, R.V.; Hashmi, S.I. Effect of hydrocolloid (guar gum) incorporation on the quality characteristics of bread. J. Food Process. Technol. 2012, 3, 136. [CrossRef]

28. Tebben, L.; Shen, Y.; Li, Y. Improvers and functional ingredients in whole wheat bread: A review of their effects on dough properties and bread quality. Trends Food Sci. Technol. 2018, 81, 10-24. [CrossRef]

29. Matsushita, K.; Santiago, D.M.; Noda, T.; Tsuboi, K.; Kawakami, S.; Yamauchi, H. The bread making qualities of bread dough supplemented with whole wheat flour and treated with enzymes. Food Sci. Technol. Res. 2017, 23, 403-410. [CrossRef]

30. Driss, D.; Bhiri, F.; Siela, M.; Bessess, S.; Chaabouni, S.; Ghorbel, R. Improvement of breadmaking quality by xylanase GH11 from Penicillium occitanis Pol6. J. Texture Stud. 2012, 44, 75-84. [CrossRef]

31. Ghoshal, G.; Shivhare, U.; Banerjee, U. Effect of xylanase on quality attributes of whole-wheat bread. J. Food Qual. 2013, 36, 172-180. [CrossRef]

32. Bock, J.E. Chapter 9-Enzymes in breadmaking. In Improving and Tailoring Enzymes for Food Quality and Functionality, 1st ed.; Yada, R.Y., Ed.; Woodhead Publishing: Vancouver, BC, Canada, 2015.

33. Cai, Y.; Corke, H.; Wang, D.; Li, W. Buckwheat: Overview. Encycl. Food Grains 2016, 1, 307-315. [CrossRef] 
34. Corsetti, A.; Gobbetti, M.; De Marco, B.; Balestrieri, F.; Paoletti, F.; Russi, L.; Rossi, J. Combined effect of sourdough lactic acid bacteria and additives on bread firmness and staling. J. Agric. Food Chem. 2000, 48, 3044-3051. [CrossRef]

35. Bonta, V.; Marghitas, L.A.; Stanciu, O.; Laslo, L.; Dezmirean, D.; Bobis, O. High-performance liquid chromatographic analysis of sugars in Transylvanian honeydew honey. Bull. Univ. Agric. Sci. Vet. Med. Cluj-Napoca-Anim. Sci. Biotechnol. 2008, 65, 229-232.

36. Bunea, A.; Rugina, D.O.; Pintea, A.M.; Sconta, Z.; Bunea, C.I.; Socaciu, C. Comparative polyphenolic content and antioxidant activities of some wild and cultivated blueberries from Romania. Not. Bot. Horti Agrobot. 2011, 39, 70-76. [CrossRef]

37. Păucean, A.; Man, S.M.; Chiş, M.S.; Mureşan, V.; Pop, C.R.; Socaci, S.A.; Mureşan, C.C.; Muste, S. Use of pseudocereals preferment made with aromatic yeast strains for enhancing wheat bread quality. Foods 2019, 8, 443. [CrossRef]

38. Urcan, A.D.; Criste, A.D.; Dezmirean, D.S.; Mărgăoan, R.; Caeiro, A.; Campos, M.G. Similarity of data frombee bread with the same taxa collected in India and Romania. Molecules 2018, 23, 2491. [CrossRef]

39. Chiş, M.S.; Păucean, A.; Man, S.M.; Vodnar, D.C.; Teleky, B.-E.; Pop, C.R.; Stan, L.; Borsai, O.; Kadar, C.B.; Urcan, A.C.; et al. Quinoa sourdough fermented with Lactobacillus plantarum ATCC 8014 designed for gluten-free muffins-A powerful tool to enhance bioactive compounds. Appl. Sci. 2020, 10, 7140. [CrossRef]

40. Đorđević, T.; Šiler-Marinković, S.S.; Dimitrijević-Branković, S.I. Effect of fermentation on antioxidant properties of some cereals and pseudo cereals. Food Chem. 2010, 119, 957-963. [CrossRef]

41. Chiş, M.S.; Păucean, A.; Man, S.M.; Mureșan, V.; Socaci, S.A.; Pop, A.; Stan, L.; Rusu, B.; Muste, S. Textural and sensory features changes of gluten free muffins based on rice sourdough fermented with Lactobacillus spicheri DSM 15429. Foods 2020, 9, 363. [CrossRef] [PubMed]

42. Chiș, M.S.; Păucean, A.; Stan, L.; Mureșan, V.; Vlaic, R.A.; Man, S.; Muste, S. Lactobacillus plantarum ATCC 8014 in quinoa sourdough adaptability and antioxidant potential. Rom. Biotechnol. Lett. 2018, 23, 13581-13591.

43. Man, S.M.; Păucean, A.; Călian, I.D.; Mureșan, V.; Chiş, M.S.; Pop, A.; Mureșan, A.; Bota, M.; Muste, S. Influence of fenugreek flour (Trigonella foenum-graecum L.) addition on the technofunctional properties of dark wheat flour. J. Food Qual. 2019, 2019, 8635806. [CrossRef]

44. Kim, S.L.; Son, Y.K.; Hwang, J.J.; Kim, S.K.; Hur, H.S.; Park, C.H. Development and utilization of buckwheat sprouts as functional vegetables. Fagopyrum 2001, 18, 49-54.

45. Lee, E.H.; Kim, C.J. Nutritional changes of buckwheat during germination. Korea J. Food Cult. 2008, 23, 121-129.

46. Požrl, T.; Kopjar, M.; Kurent, I.; Hribar, J.; Jänes, A.; Simčič, M. Phytate degradation during breadmaking: The influence of flour type and breadmaking procedures. Czech J. Food Sci. 2009, 27, 29-38. [CrossRef]

47. Qin, P.; Wang, Q.; Shan, F.; Hou, Z.; Ren, G. Nutritional composition and flavonoids content of flour from different buckwheat cultivars. Int. J. Food Sci. Technol. 2010, 45, 951-958. [CrossRef]

48. Mazza, G.; Oomah, B.D. Buckwheat. In Encyclopedia of Food Sciences and Nutrition; Caballero, B., Trugo, L.C., Finglas, P.M., Eds.; Academic Press: London, UK, 2003; pp. 692-699.

49. Codină, G.; Mironeasa, S.; Voica, D.; Mironeasa, C. Multivariate analysis of wheat flour dough sugars, gas production, and dough development at different fermentation times. Czech J. Food Sci. 2013, 31, 222-229. [CrossRef]

50. Sahlström, S.; Park, W.; Shelton, D.R. Factors influencing yeast fermentation and the effect of LMW sugars and yeast fermentation on hearth bread quality. Cereal Chem. J. 2004, 81, 328-335. [CrossRef]

51. Nam, T.G.; Lim, Y.J.; Eom, S.H. Flavonoid accumulation in common buckwheat (Fagopyrum esculentum) sprout tissues in response to light. Hortic. Environ. Biotechnol. 2018, 59, 19-27. [CrossRef]

52. Yiming, Z.; Hong, W.; Linlin, C.; Zhou, X.; Wen, T.; Xinli, S. Evolution of nutrient ingredients in tartary buckwheat seeds during germination. Food Chem. 2015, 186, 244-248. [CrossRef] [PubMed]

53. Ren, S.-C.; Sun, J.-T. Changes in phenolic content, phenylalanine ammonia-lyase (PAL) activity, and antioxidant capacity of two buckwheat sprouts in relation to germination. J. Funct. Foods 2014, 7, 298-304. [CrossRef]

54. Singh, R.; Babu, S.; Avasthe, R.K.; Yadav, G.S.; Chettri, T.K.; Phempunadi, C.D.; Chatterjee, T. Bacterial inoculation effect on soil biological properties, growth, grain yield, total phenolic and flavonoids contents of common buckwheat (Fagopyrum esculentum Moench) under hilly ecosystems of North-East India. Afr. J. Microbiol. Res. 2015, 9, 1110-1117. 
55. Inglett, G.E.; Chen, D.; Berhow, M.; Lee, S. Antioxidant activity of commercial buckwheat flours and their free and bound phenolic compositions. Food Chem. 2011, 125, 923-929. [CrossRef]

56. Han, H.-M.; Koh, B.-K. Antioxidant activity of hard wheat flour, dough and bread prepared using various processes with the addition of different phenolic acids. J. Sci. Food Agric. 2010, 91, 604-608. [CrossRef]

57. Akinyede, A.; Amoo, I. Chemical and functional properties of full fat and defatted cassia fistula seed flours. Pak. J. Nutr. 2009, 8, 765-769. [CrossRef]

58. Bhavsar, G.; Sawate, A.R.; Kshirsagar, R.B.; Chappalwar, V.M. Studies on physico-chemical characteristics of buckwheat and its exploration in breads as functional food. Int. J. Eng. Res. Technol. 2013, 2, 3971-3980.

59. Shewry, P.R.; Hey, S.J. The contribution of wheat to human diet and health. Food Energy Secur. 2015, 4, 178-202. [CrossRef]

60. Drobot, V.; Semenova, A.; Smirnova, J.; Myhonic, L. Effect of buckwheat processing products on dough and bread quality made from whole-wheat flour. Int. J. Food Stud. 2014, 3, 1-12. [CrossRef]

61. Selimović, A.; Miličevic, D.; Jašić, M.; Selimović, A.; Ačkar, Đ.; Pešić, T. The effect of baking temperature and buckwheat flour addition on the selected properties of wheat bread. Croat. J. Food Sci. Technol. 2014, 6, 43-50.

62. Bojňanská, T.; Chlebo, P.; Gažar, R.; Horna, A. Buckwheat-enriched bread production and its nutritional benefits. Eur. J. Plant Sci. Biotechnol. 2009, 3, 49-55.

63. Hidalgo, A.; Brandolini, A. Bread-Bread from Wheat Flour. Encyclopedia of Food Microbiology; Batt, C.A., Tortorello, M.L., Eds.; Academic Press: London, UK, 2014; Volume 1, pp. 303-308.

64. Chlopicka, J.; Pasko, P.; Gorinstein, S.; Jedryas, A.; Zagrodzki, P. Total phenolic and total flavonoid content, antioxidant activity and sensory evaluation of pseudocereal breads. LWT 2012, 46, 548-555. [CrossRef]

65. Costantini, L.; Lukšič, L.; Molinari, R.; Kreft, I.; Bonafaccia, G.; Manzi, L.; Merendino, N. Development of gluten-free bread using tartary buckwheat and chia flour rich in flavonoids and omega-3 fatty acids as ingredients. Food Chem. 2014, 165, 232-240. [CrossRef] [PubMed]

66. Martinez-Villaluenga, C.; Michalska, A.; Frias, J.; Piskuła, M.K.; Vidal-Valverde, C.; Zieliński, H. Effect of flour extraction rate and baking on thiamine and riboflavin content and antioxidant capacity of traditional rye bread. J. Food Sci. 2009, 74, C49-C55. [CrossRef] [PubMed]

67. Moore, J.; Luther, M.; Cheng, Z.; Yu, L. (Lucy) Effects of baking conditions, dough fermentation, and bran particle size on antioxidant properties of whole-wheat pizza crusts. J. Agric. Food Chem. 2009, 57, 832-839. [CrossRef]

68. Karrar, E.M.A. A review on: Antioxidant and its impact during the bread making process. Int. J. Nutr. Food Sci. 2014, 3, 592. [CrossRef]

69. Yu, L.; Nanguet, A.-L.; Beta, T. Comparison of antioxidant properties of refined and whole wheat flour and bread. Antioxidants 2013, 2, 370-383. [CrossRef]

70. Amigo, J.M.; Alvarez, A.D.O.; Engelsen, M.M.; Lundkvist, H.; Engelsen, S.B. Staling of white wheat bread crumb and effect of maltogenic $\alpha$-amylases. Part 1: Spatial distribution and kinetic modeling of hardness and resilience. Food Chem. 2016, 208, 318-325. [CrossRef]

71. Moradi, M.; Bolandi, M.; Karimi, M.; Nahidi, F.; Baghaei, H. Improvement of gluten-free taftoon bread properties during storage by the incorporation of potato powder (Satrina V.), guar gum, sodium caseinate and transglutaminase into the matrix. J. Food Meas. Charact. 2020, 14, 2282-2288. [CrossRef]

72. Savkina, O.; Kuznetsova, L.; Burykina, M.; Kostyuchenko, M.; Parakhina, O. The influence of the flour amylolytic enzymes activity, dosage of ingredients and bread making method on the sugar content and the bread quality. Agron. Res. 2020, 18, 1873-1887.

73. Shah, A.R.; Shah, R.; Madamwar, D. Improvement of the quality of whole wheat bread by supplementation of xylanase from Aspergillus foetidus. Bioresour. Technol. 2006, 97, 2047-2053. [CrossRef] [PubMed]

74. Encina-Zelada, C.R.; Cadavez, V.; Monteiro, F.; Teixeira, J.A.; Gonzales-Barron, U. Physicochemical and textural quality attributes of gluten-free bread formulated with guar gum. Eur. Food Res. Technol. 2019, 245, 443-458. [CrossRef]

75. Turkut, G.M.; Cakmak, H.; Kumcuoglu, S.; Tavman, S. Effect of quinoa flour on gluten-free bread batter rheology and bread quality. J. Cereal Sci. 2016, 69, 174-181. [CrossRef]

76. Morais, E.; Cruz, A.G.; Faria, J.; Bolini, H.M.A. Prebiotic gluten-free bread: Sensory profiling and drivers of liking. LWT 2014, 55, 248-254. [CrossRef]

77. Ghodke, S.K. Effect of guar gum on dough stickiness and staling in chapatti-an Indian unleavened flat bread. Int. J. Food Eng. 2009, 5, 1-21. [CrossRef] 
78. Starowicz, M.; Koutsidis, G.; Zieliński, H. Sensory analysis and aroma compounds of buckwheat containing products-A review. Crit. Rev. Food Sci. Nutr. 2017, 58, 1767-1779. [CrossRef]

79. Bilgiçli, N.; Ibanoğlu, Ş. Effect of pseudo cereal flours on some physical, chemical and sensory properties of bread. J. Food Sci. Technol. 2015, 52, 7525-7529. [CrossRef]

80. Xu, F.-Y.; Gao, Q.-H.; Ma, Y.-J.; Guo, X.; Wang, M. Comparison of tartary buckwheat flour and sprouts steamed bread in quality and antioxidant property. J. Food Qual. 2014, 37, 318-328. [CrossRef]

Publisher's Note: MDPI stays neutral with regard to jurisdictional claims in published maps and institutional affiliations.

(C) 2020 by the authors. Licensee MDPI, Basel, Switzerland. This article is an open access article distributed under the terms and conditions of the Creative Commons Attribution (CC BY) license (http://creativecommons.org/licenses/by/4.0/). 